\title{
Evaluating the Damage Content of Karbandi Using Frequency Domain Analysis (Case Study: Timche Haj-Mohammad-Qoli of Tabriz Historic Bazaar)
}

Elshan Ahani ( $\nabla$ elshan.ahani@gmail.com )

Shanghai Jiao Tong University https://orcid.org/0000-0002-8483-6547

Ali Ahani

Istanbul Technical University: Istanbul Teknik Universitesi

\section{Research Article}

Keywords: Tabriz bazaar complex, Karbandi, Structural morphology, Fourier analysis, Damage content, Near-field ground motion

Posted Date: October 27th, 2021

DOl: https://doi.org/10.21203/rs.3.rs-1013551/v1

License: (c) (i) This work is licensed under a Creative Commons Attribution 4.0 International License.

Read Full License 


\section{Abstract}

In this study, an alternate method of evaluating structural systems, especially for the sensitive structures with historical importance by applying Fourier Transform (FT) to the damage ratio of time history outcome in the frequency domain has been introduced. The concept of damage content (DC) regarding the mechanical characteristics of the used material, including plastic strain, failure plane, and ultimate load-bearing capacity, along with drift value, record selection criteria, and architectural aspects, have been employed. Due to its valuable aesthetic and architectural view, Timche Haj-Mohammad-Qoli of Tabriz Historic Bazaar, one of the traditional covered spaces with the complicated configuration of spatial masonry intersecting arches, was selected for the assessment in the current study. The required experimental samples for obtaining the mechanical properties and relevant geometrical measurements to prepare the numerical model of the structure obtained. The strong ground motions according to seismological and geological characteristics of the construction site selected. The records with different durations were merged by Fourier Transform (FT) and Damage Content (DC) analysis. According to the outcomes, the damage state of the structure due to the imposed strong motion at every stage of the lateral loading from the failure initiation to the final collapse was observable. As a direct outcome of this study, the vulnerability concerning the near-field earthquakes is more tangible than far-field earthquakes. The provided methodology could have proper use in future similar studies for evaluating the performance of the structures.

\section{Introduction}

Several historical and ancient masonry buildings are belonging to the vast circle of arches and vaults. Aesthetic, slenderness, and load-bearing capability make these structures attractive for manipulation in the construction industry of monumental structures both in past and present (Sarhangi, 1999; Sevim et al., 2011; Sadeghi et al., 2019). However, numerous vulnerability points of these structures, to a large extent because of the limited load-bearing capacity of the masonry elements, make them laid open to natural hazards (D'Ayala and Speranza, 2003; Lourenço and Roque, 2006; Pasticier et al., 2008; Asteris et al., 2014; Asteris et al., 2019). Severe damages and failures caused by earthquakes demonstrate that masonry structures, including masonry arches and vaults on the top, are one of the most vulnerable elements in historical monuments (Lagomarsino and Podestà, 2004; Dogangun and Sezen, 2012; Formisano and Marzo, 2017; Cusano et al., 2019). Iran is a host country for numerous masonry structures that demonstrated the vulnerability of masonry arches to strong ground motions in numerous earthquakes consist of but not limited to the Tabas earthquake of 1978, the Manjil earthquake of 1990, the Ahar-Varzeghan earthquake of 2012, and the Sarpol-e Zahab earthquake of 2018.

The typologies of the heritage buildings are usually capable of resisting the gravity loads. However, they are weak to resist the seismic forces, and in some cases, vehemently ruined due to severe earthquakes. As a result, the seismic events gave a strong motivation towards the understanding and the interpretation of the seismic response of masonry structures to different structural typologies (Bell, 1903; IASS, 1984; Nooshin, 1998), especially if exposed to high seismic hazards or unfavorable soil 
properties(Motro, 2009). Several studies were devoted to analyzing historical masonry structures, such as churches, monuments, bazaars, and palaces (Haj Gasemi, 2004; Stach, 2010; Ahmadi, 2014; Kawaguchi, 2016; Aghabeigi et al., 2020).

Giuffre $(1991 ; 1993)$ demonstrated the necessity of a multidisciplinary technique for seismic assessment of historical masonries. Binda and Saisi (2005) indicated the importance of on-site observations and experimental investigations to achieve the reliable structural information of masonry buildings such as geometry, structural details, crack patterns, etc. The importance of modeling strategies to assess the seismic response of masonry structures utilizing macro elements instead of the conventional evaluation of the structural behavior was suggested by Lagomarsino et al. (2004) in another study. Doglioni et al. (1994) used the simplified techniques of kinematic mechanism to assess the seismic response of the church. Lourenço (2002) showed even if the definition of the parameters to model a non-linear numerical simulation demonstrates difficulties in many cases, it is advantageous to compare the other modeling methods to assess the seismic behavior of historic structures. More in advance during the past decade, investigations on the simulations of three-dimensional, geometrically complex structures are performed to evaluate the seismic behavior of historical buildings (Casarin and Modena, 2008; Boscato et al., 2014; Castellazzi et al., 2018; Mendes et al., 2020). As yet, modeling strategies using numerical techniques as distinct element method (DEM) or finite element method (FEM), considering non-linear material properties, are becoming a standard procedure also in the simulation of full-scale structures (Roca, 2001; Rots, 2001; Ramos and Lourenço, 2004). Most of the historical monuments and ancient buildings were made of masonry elements, including but not limited to clay bricks, stones, raw clays, etc. Advances in using numerical methods to ease the calculation process in the design of structural elements demonstrate the complexity of considering the presence of masonry elements because of their unpredictable post-failure behavior and utilization inside the old-fashioned buildings, which made the process more difficult than prognostications. Hence, many researchers to predict the behavioral content of masonries in historical buildings used FEM (Chiarugi et al., 1993; Croci, 1995; Roca et al., 2010; Atamturktur and Laman, 2012). The complicated geometric shape of many historical buildings constrains the modeling procedure even in FEM software in which the meshing is affected by numerous parameters, including convergence and unity problems. To solve this issue, new methods of modeling named simplified micro modeling and macro modeling with more simple geometry are used by the researchers (Betti and Galano, 2012; Vicente et al., 2018; Ahani et al., 2019). Predicting the behavioral content of masonries due to diversity of the used materials and load-displacement indices confronted with sensible errors. Hence, numerous behavioral contents were introduced by researchers to provide a better perspective for the behavior of masonry elements many of which are also approved by prominent standards and design codes (FEMA 308, 1999; Eurocode 8, 2005). This is while many design codes and standards remained silent about the behavioral content of the masonry elements (ICC, 2003; Issue No. 120, 2003; ACI530, 2011; Standard 2800, 2015). Concrete damage plasticity as an empirical method was used in many experimentally and numerically performed research studies (Wang and Hsu 2001; Majewski, 2003). The accuracy of this method compared to the others like concrete 
smeared crack or Drucker-pruger had an appropriate convergence. Hence, this method is introduced by Eurocode 2 (2005) for anticipating the post-failure behavior of concrete elements.

Timche Haj-Mohammad-Qoli of Tabriz Historic Bazaar, as one of these Cultural Heritages, was considered as the study case of this research for further evaluation of its' structural morphology and damage content. Basic steps for evaluating the masonry buildings are the achievement of adequate knowledge of structure and materials and the consecutive use of the obtained data for seismic evaluation purposes. Therefore, common steps of brief historical and architectural description of the Tabriz bazaar and Timche Haj-Mohammad-Qoli, an on-site observation to identifying the current status of the structure, and the seismic assessment of the structure with the help of Nonlinear Time History Analysis (NTHA), and Fourier Analysis (FA) have performed in the current study. It is essential to add that the assessment of masonry structure carried out in two states of evaluating under gravity loadings and joint gravity and seismic loadings.

\section{Research Significance}

The most controversial issue in the survey of historical monuments is related to the prevailing structural vulnerability, which is according to cultural significance, architectural esthetic, and consideration as national monuments may intensify the possibility of further excavations for these structures. In this regard, numerous Standards (FEMA 306, 1998; FEMA 308, 1999; ACI 228.2R-98, 2004; ACI 364.1R-07, 2007; ACl 201.1R-08, 2008; ACl 369R-11, 2011; ACI 562M-13, 2013; ASTM C597-16, 2016) introduced some inspecting methods accompanied by non-destructive tests (NDT) to acquire an assumption for the current stance of the structures. While in some cases, visional inspections with the assistance of NDT tests won't provide sufficient information about the studied structures. Hence, Standards (ASCE/SEI 3103, 2003; ACI 364.1R-07, 2007; ASCE/SEl 41-06, 2007; ACI 562M-13, 2013; ASTM C496/C496M-17, 2017; ASTM C1314-18, 2018; ASTM C42/C42M-20, 2020; ASTM C39/C39M-21, 2021) also introduced destructive tests as an ultimate and irreplaceable alternative for structural evaluation of the structures. In this condition, since the facade, stability, and the integrity of the historical monuments is substantially important (FEMA 172, 1992; Standards for the Treatment of Historic Properties with Guidelines for Preserving, Rehabilitating, Restoring \& Reconstructing Historic Buildings, 1995; ASCE/SEI 31-03, 2003; FEMA P-774, 2009), the amount and location of the test become an important parameter in seismic assessment, which may vary according to the principles of the standards (FEMA 274, 1997; FEMA 306, 1998; ASCE/SEI 31-03, 2003, ACI 369R-11, 2011).

While limited Standards provided protocols for testing and getting specimen samples from the historical structures (ASCE/SEI 31-03, 2003; ASCE/SEI 41-06, 2007), most of the standards (ATC-40, 1996; FEMA 306, 1998; ACl 201.1R-08, 2008) introduced the destructive tests for modern structures, which were not applicable for historical masonries. Thus, the provided methods may not satisfy the required limits of historical monuments, and therefore while the destructive tests may have limited eligibilities (Standards for the Treatment of Historic Properties with Guidelines for Preserving, Rehabilitating, Restoring \& Reconstructing Historic Buildings, 1995; 36 CFR 68, 2012) and the outcomes from NDT tests may not 
comprehensively reliable for the long-lasted human heritages a thorough numerical evaluation may be employed. In addition to the difficulty of finding the failure amount and location, determining them may of high value for the historical structures since the financial worthiness of these cultural heritages is incomparable with typical engineering structures. In this regard, many studies have evaluated the failure parameters of historical masonries (Zampieri et al., 2016; Zampieri et al., 2017; Zampieri et al., 2018; Galassi et al., 2018; Chen et al., 2019). According to carried out studies and the provided principles of the regulations and standards, the failure parameters were categorized as but not limited to soil settlements or support movements (FEMA 172, 1992; FEMA 274, 1997; Portioli and Cascini, 2017; Galassi et al., 2018; Zampieri et al., 2018), failure due to ground motion excitations (FEMA 172, 1992; Eurocode 8, 2005; ASCE/SEl 41-06, 2007; Severini et al., 2018; Carozzi et al., 2018; Zampieri et al., 2019), weathering (FEMA 172, 1992; FEMA 274, 1997; Boughton and Falconer, 2001; ASCE/SEl 41-06, 2007; Sarhosis et al., 2016; Solan et al., 2020), scouring (Scozzese et al., 2019; Solan et al., 2019; Solan et al., 2020), etc. Considering the mentioned implementation, an effective and economical method for evaluating these types of structures may gain attention by many researchers.

In the current study, with the assistance of Nonlinear Time History Analysis (NTHA) and Furrier Analysis (FA), the seismic assessments for evaluating the performance of a building in the loading period of the structure and the selected earthquake records by the combination of the responses of them and utilizing of the Damage Content (DC) parameter to view the circumstance of the structure in every step of the seismic loading have been introduced. The introduced method cooperating with Incremental Dynamic Analysis (IDA) may provide more precise information about the lateral behavior of any other kinds of structures at every stage of surveying. Historical monuments located in seismically active places are the most vulnerable heritages of the commonwealths (Cavalagli et al., 2017; Pellegrini et al., 2018; Severini et al., 2018; Öztürk et al., 2019; Zampieri et al., 2019). Since the Middle East is the host for considerable numbers of historical monuments, especially masonry space domes, this study is involved with the seismic assessment of the Timche Haj-Mohammad-Qoli of Tabriz Historic Bazaar, which is considered one of the world heritage of UNESCO.

\section{Masonry Space Structures}

Jamshid Al-Kashani, the famous mathematician and astronomer in the early $15^{\text {th }}$ Century to design the Ulug Beg observatory with larger spans, provided a specific definition of arches and vaults, and gather related knowledge in a book named Meftah Al-Hesab (Al-Kashani, 1427). From his viewpoint, the arch is a curved shape that has been used for the spanning of the gap and has a considerable depth. He redefined Chefd[1] and Azj[2] architectural terminologies. The final chapter of the study was devoted to Chefd and its definitions. There is also valuable information regarding the drawing arches and length of spans they can bear. Graham Bell introduced the tetrahedral space frame as an appropriate form for threedimensional structures, which was a significant breakthrough for space structures (Bell, 1903). After the invention of new types of space structures, the definition of space structure improved. IASS Committee defined the space frame as a structural system, assembled of linear elements so arranged that the loads 
are transferred in a three-dimensional manner. The constituent elements may be two-dimensional in some cases. Macroscopically, a space frame often takes the form of a flat or curved surface (IASS, 1984). The formal definition for space structures has been given by Nooshin (1998), in which the term space structure refers to a structural system that involves three dimensions. According to these definitions, equal presence in three dimensions is the most outstanding feature of the space structures. This definition resides considerable extent of the historical structures in the circle of space structures. Masonry domes such as Karbandi should consider as a space structure as an instance of this definition. Before introducing steel as a load-bearing element in engineering, masonries were the dominant materials for structural uses, especially in ancient civilizations like Iran, which contains numerous masterworks like bazaar complexes, mosques, bridges, etc., have erected by masonries.

\subsection{Karbandi}

Based on precision, Al-Kashani defines 5 types of Chefds, the first of which is a circle divided into six parts that can cover spans with a $5.2 \mathrm{~m}$ length. The second type is also has a circular shape divided into eight equal sections. The angle between these sections was $45^{\circ}$. The Chefd can bear spans with the length of $5.2 \mathrm{~m}$ to $15.6 \mathrm{~m}$. The third type was obtained by dividing the span radius into 8 parts that lead to getting center points of the bottom and top arches (Memarian et al., 2014). This type of arch is suitable to use in spans with more than $10.4 \mathrm{~m}$ lengths. The definition of the fourth and fifth types of Chefd could also be traced in Meftah Al-Hesab correspondingly (Al-Kashani, 1427). The climax of composition in aesthetic and structural applicability could be reflected in the fifth type of Chefd, in which to get the vault, two lines were directed to the span Pakar[3].

The described Chefds in Meftah Al-Hesab and their use in harmony become the key basis information of Karbandi in next generations. In Figure 1 the Chefd types categorized by Al-Kashani (1427) are demonstrated.

According to Papadopoulo and Jazanī (1989), Karbandi was derived from rolling squares inscribed in a circle. Sharbaf (2006), along with Pirnia and Bozorgmehri (2006), categorized Karbandi into general Shaghooli[4] and Sarseft[5] types with the shape of hexadecagon and other geometrical shapes in a simple form or made from the intersection of two shapes. Lu and Steinhardt (2007) introduced Karbandi as an advanced architectural approach of transferring loads resulted from the premier knowledge of geometry and mathematics of its founders. Theoretical geometry mainly focuses on lines surfaces area of three-dimensional objects, and the essence of practical geometry is to implement the science of geometry in wood, metal, brick, and other tangible things (Papadopoulo and Jazanī, 1989). Garofalo (2016) introduced Karbandi as a kind of arched shape roofing based on Islamic star patterns. In brief, Karbandi is employing the geometrical pattern of one or multiple Chefds in harmony and aspect of subtlety, the outcomes of which would have a structural performance and application to the users. Examples of Karbandis consist of the Mausoleum of Baba Tahir (Hamadan, Iran), Mir-i-Arab Madrasa (Bukhara, Uzbekistan), Haidarzadeh Museum of Coin and Anthropology (Tabriz, Azerbaijan), etc. 
Karbandis widely used in the entrances, arcades, and intersections of historical Bazaars. Tabriz historical bazaar is one of the most landmark bazaars with numerous Karbandis in its different parts. The continuity of using Karbandi is highly demanded in contemporary Islamic Architecture but requires a precise understanding of geometrical and structural aspects of ancient Karbandis to achieve a modern design and construction strategy to meet new requirements.

\subsection{Timche Haj-Mohammad-Qoli}

The building of Timche Haj-Mohammad-Qoli dates back to the early Qajar dynasty (1810s). The architectural evaluation of the type and design of the vaults concur aesthetical and infrastructure fundamentals of that period. Although the design principles and rationale may root back to the basis of Karbandi, Astronomical requirements, Space creation, and philosophy of using Chefd as an accurate object for arch creation, the further details of which have been discussed formerly.

\subsubsection{Location}

Tabriz Historic Bazaar Complex consists of numerous masonry space structures and various fundamental features of masonry structural systems. These features are architectural and structural morphologies, force flow and force management in the masonries, and perception of the collaboration among structural elements. Timche[6] Haj-Mohammad-Qoli, with 11.5 meters diameter, is one of the covered spaces masterpieces of Tabriz bazaar with a sophisticated configuration of spatial masonry intersecting arches and selected for further excavation in the current study. The Bazaar has various Timches and Rastehs[7], which have covered with different masonry curved surfaces such as dome, vault, and Karbandi. The applications of Timches in the past were the goods wholesale. The coverture of all the Timches is an arched shape, most of which have been made by using Karbandi. In Figure 2, the location and section cuts of the sophisticated Karbandi of the Haj-Mohammad-Qoli Timche are presented. It has been located in the southern part of the Historical Bazar. The main part of the Timche is located at the northeast corner of the Bazar Complex. It has accessibilities from four sides. Appropriate connectivity with neighbor elements, especially in the east-west axis, makes the strong bond with Bazar texture. This Timche has been built based on orderly and comprehensive geometry and symmetrical shape in north-south and west-east axis.

\subsubsection{Geometry}

It had been constructed by using Karbandi. The plan of the structure was the combination of an eight[8] and a half-eight[9] plan that were rotated around the central point with the $45^{\circ}$ angle and coincide with the pattern at the beginning. Harmoniously, the roofing system consisted of a dome shape arch at the center and four half-arches on the sides. The middle part was filled with sixteen-wing Shamseh[10] and brick domes with simple ornamentations. In comparison to others, the Karbandi of Haj-Mohammad-Qoli 
Timche has the most sophisticated architectural structure. Considering Sharbaf (2006), the Timche could consider as Sarseft Karbandi made from the intersection of two simple hexadecagons, though its geometry is slightly different. The geometry creation leads to the development of 16 intersecting equal chords between the dividing points with identical arches located on each chord. Parallel to the skeleton forming the Timche from the inside, another Chefd network has been used in the exterior skeleton of the structure unseen from interior space. The employed arches in the structural elements of this Karbandi, according to the Al-Kashani (1427) categorization, most probably reside in 2nd or 3rd type Chefd. Figure 3 presents the final feature of the Karbandi of Timche Haj-Mohammad-Qoli from inner and outer perspectives.

\section{Structural Evaluation}

Due to its historical value, the structural evaluations of the Timche that may consist of both nondestructive and destructive tests confronted with difficulties. Thus, up to the feasibilities, the assessments led to non-destructive tests. The geometrical faces, length of the spans, dimensions of the arches, the dome height, and other requirements according to architectural principles were performed. The visual inspections determined that the properties of the material used within the masonry consisted of clay brick and lime mortar. Since getting direct samples from the masonry were ineligible, a request for acquiring unit and joint samples from Cultural Heritage, Handicrafts, and Tourism Organization of East Azerbaijan, were enclosed. The bureau yielded limited handy numbers of masonry units extracted from the Timche and the combination of the used lime mortar inside the building, which is not presentable due to passive defense factors. To grasp the characteristics of the materials, masonry prisms according to the instructions of the American Society for Testing and Materials (ASTM) were constructed in the laboratory.

\subsection{Material Properties}

Determining the tensile behavior of masonry prisms according to the principles of both ASTM E518/E518M-10 (2010) and ASTM E519/E519M-10 (2010) standards are viable. However, since ASTM E519/E519M-10 (2010) was not applicable for lime mortars, the tensile and bending characteristics of the studied materials regarding the principles of ASTM E518/E518M-10 (2010) have determined. The compressive behavior of the studied materials was performed according to ASTM C1314-07 (2007). In Table 1 and Table 2, details of the experimental outcomes of the studied samples for flexural bond strength and compressive strength have presented, respectively. In Figure 4, laboratory tests for determining compression strength and flexural bond strength of two specimens have been brought.

Table 1: Laboratory performed tests to determine the flexural bond strength of the studied samples according to ASTM E518/E518M-10 (2010) 


\begin{tabular}{|c|c|c|c|c|c|c|c|c|}
\hline $\begin{array}{l}\text { Specimen } \\
\text { No. }\end{array}$ & $\begin{array}{l}\text { Test } \\
\text { Method }\end{array}$ & $\begin{array}{l}\text { Age at } \\
\text { Test } \\
\text { (Days) }\end{array}$ & $\begin{array}{l}\text { Avg. } \\
\text { Width } \\
\text { (mm) }\end{array}$ & $\begin{array}{l}\text { Avg. } \\
\text { Depth } \\
(\mathrm{mm})\end{array}$ & $\begin{array}{l}\text { Avg. } \\
\text { Length } \\
\text { (mm) }\end{array}$ & $\begin{array}{l}\text { Weight } \\
(\mathrm{kN})\end{array}$ & $\begin{array}{l}\text { Max } \\
\text { Load } \\
(\mathrm{kN})\end{array}$ & $\begin{array}{l}\text { Strength } \\
(\mathrm{MPa})\end{array}$ \\
\hline 1 & $A$ * & 28 & 201 & 101 & 460 & 0.152 & 0.260 & 0.084 \\
\hline 2 & $A$ * & 28 & 200 & 100 & 460 & 0.150 & 0.203 & 0.073 \\
\hline 3 & $A$ * & 28 & 202 & 101 & 461 & 0.155 & 0.257 & 0.083 \\
\hline 4 & $A$ * & 28 & 201 & 102 & 460 & 0.153 & 0.277 & 0.086 \\
\hline 5 & $A$ * & 28 & 201 & 99 & 460 & 0.151 & 0.188 & 0.070 \\
\hline Average & - & - & 201 & 101 & 460 & 0.152 & 0.237 & 0.079 \\
\hline Deviation & - & - & 0.71 & 1.14 & 0.45 & 0.002 & 0.039 & 0.007 \\
\hline CV ** & - & - & 0.004 & 0.011 & 0.001 & 0.013 & 0.165 & 0.092 \\
\hline
\end{tabular}

* It is a third-point loading method that was discussed in ASTM E518 with further details.

** Coefficient of Variation.

Table 2: Laboratory performed tests to determine the compressive strength of the studied samples according to ASTM C1314-07 (2007)

\begin{tabular}{|llllllll|}
\hline $\begin{array}{l}\text { Specimen } \\
\text { No. }\end{array}$ & $\begin{array}{l}\text { Age at } \\
\text { Test } \\
\text { (Days) }\end{array}$ & $\begin{array}{l}\text { Avg. } \\
\text { Width } \\
(\mathrm{mm})\end{array}$ & $\begin{array}{l}\text { Avg. } \\
\text { Height } \\
(\mathrm{mm})\end{array}$ & $\begin{array}{l}\text { Avg. } \\
\text { Length } \\
(\mathrm{mm})\end{array}$ & $\begin{array}{l}\mathrm{h}_{\mathrm{p}} / \mathrm{t}_{\mathrm{p}} \\
\text { Correction } \\
\text { Factor* }\end{array}$ & $\begin{array}{l}\text { Max } \\
\text { Load } \\
(\mathrm{kN})\end{array}$ & $\begin{array}{l}\text { Strength } \\
(\mathrm{MPa})\end{array}$ \\
\hline $\mathbf{1}$ & 28 & 101 & 315 & 200 & 1.077 & 47.4 & 2.53 \\
\hline $\mathbf{2}$ & 28 & 102 & 316 & 201 & 1.076 & 51.8 & 2.72 \\
\hline $\mathbf{3}$ & 28 & 102 & 318 & 200 & 1.077 & 48.1 & 2.54 \\
\hline $\mathbf{4}$ & 28 & 101 & 318 & 199 & 1.079 & 51.0 & 2.74 \\
\hline $\mathbf{5}$ & 28 & 100 & 318 & 200 & 1.084 & 50.1 & 2.72 \\
\hline Average & - & 101 & 317 & 200 & 1.079 & 50 & 2.65 \\
\hline Deviation & - & 0.84 & 1.41 & 0.71 & 0.003 & 1.88 & 0.10 \\
\hline CV ** & - & 0.008 & 0.004 & 0.004 & 0.003 & 0.038 & 0.040 \\
\hline
\end{tabular}

* It is the ratio of the prism height to the least lateral dimension of it according to ASTM C1314.

$\star \star$ Coefficient of Variation.

Considering the erosion, weathering, corrosion, etc., and the historical content of the perusing structure, the accuracy of the excerpted outcomes from the experimentally evaluated specimens may be affected by these factors. However, since the precision of any other non-destructive tests including but not limited 
to Schmidt hammer test, ultraviolet test, ultrasonic test, or the imposed damage from destructive tests like coring could not be acceptable the prepared and tested samples according to the principles of ASTM E518/E518M-10 (2010) were still in the advantageous position. and was selected as the criteria for evaluating the results. Experimental results and research outcomes for the compressive strength of the masonry material are in good agreement. The same condition was also observed in the ultimate strain obtained from indirect tensile tests and extracted values from the studies. By taking into account, the mentioned obtained values from the lab utilized for numerical modeling of the material behavior.

\subsection{Record Selection Criteria}

According to the principles of BHRC (2015), the strong ground motions were chosen by considering their magnitude, fault type, epicentral distance, hypocentral distance, soil type, and effective duration. Since a considerable amount of the historical strong ground motions, which took place in Tabriz, were estimated to range between 5 to 8 Richter in magnitude, all of the selected records had a magnitude larger than 6 Richter. The ilk of the most active fault in the construction geography of the Timche is strike-slip, which is located in the northern part of the city on the seismic belt of Alp-Himalaya. Most of the recorded earthquakes in the studied zone have a hypocentral depth of 10 to 20 kilometers, and the perpendicular distance of the site from the fault is about 15 kilometers. The shear wave velocity of the soil in the site ranged between $175 \mathrm{~m} / \mathrm{s}$ to $375 \mathrm{~m} / \mathrm{s}$. Thus, the records with a hypocentral distance of 0 to 50 kilometers and epicentral distance of 0 to 30 kilometers with aforementioned analogous shear velocities are the focal point of the search for similar records. Concerning the principles of BHRC (2015), the selected records considered in the search procedure should have at least 10 seconds of effective duration. Since it is located in the vicinity of both major and minor faults, almost every constructed building within the city was prone to both near-field and far-field earthquakes. This study also considered near-field records for evaluating the effects. The epicentral distance and high unorthodox values in the velocity time history were considered the signs of only-pulsed records in various research studies (Baker, 2008; Panella et al., 2017; Kohrangi et al., 2019). In this study, the most prevailing selection method has been used, in which the epicentral distances lesser than 10 kilometers were considered only-pulsed records. Eventually, 20 records of strong ground motions, half of which are only-pulsed, were selected for the current study. Since all of the befallen severe earthquakes in Tabriz were belong to the era that there are no measuring devices and there is no information about the site records, all of the relevant data collected from the Pacific Earthquake Engineering (PEER) database. It is essential to mention 16 of the selected records are conjugated, which means the record data is extracted from two different stations to resemble the nearfield and the far-field effects of the selected records. The characteristics of selected records for both nearfield and far-field ground motions have shown in Table 3.

Table 3 Ground motion records Name, Year, Station, Abbreviation and PGA 


\begin{tabular}{|c|c|c|c|c|c|}
\hline & Record Name & Year & Station & Abb & PGA \\
\hline \multirow[t]{10}{*}{$\begin{array}{l}\text { Far field Strong } \\
\text { Ground Motions }\end{array}$} & "Coyote Lake" & 1979 & $\begin{array}{l}\text { "San Juan Bautista_ } 24 \\
\text { Polk St" }\end{array}$ & CSN & 0.118 \\
\hline & $\begin{array}{l}\text { "Darfield_New } \\
\text { Zealand" }\end{array}$ & 2010 & $\begin{array}{l}\text { "Christchurch Cashmere } \\
\text { High School" }\end{array}$ & $\mathrm{DCN}$ & 0.297 \\
\hline & $\begin{array}{l}\text { "El Mayor-Cucapah_ } \\
\text { Mexico" }\end{array}$ & 2010 & $\begin{array}{l}\text { "El Centro - Meloland } \\
\text { Geot. Array" }\end{array}$ & EEN & 0.439 \\
\hline & "Imperial Valley-06" & 1979 & "Calexico Fire Station" & ICN & 0.277 \\
\hline & "Kobe_Japan" & 1995 & "Kakogawa" & KKN & 0.324 \\
\hline & "Landers" & 1992 & "Coolwater" & LCN & 0.417 \\
\hline & $\begin{array}{l}\text { "Superstition Hills- } \\
02 "\end{array}$ & 1987 & "Brawley Airport" & SBN & 0.284 \\
\hline & "Westmorland" & 1981 & "Niland Fire Station" & WNN & 0.176 \\
\hline & "Parkfield" & 1966 & $\begin{array}{l}\text { "Cholame - Shandon } \\
\text { Array \#8" }\end{array}$ & $\mathrm{PCN}$ & 0.272 \\
\hline & "Duzce_Turkey" & 1999 & "Lamont 1062" & DLN & 0.259 \\
\hline \multirow{10}{*}{$\begin{array}{l}\text { Near field Strong } \\
\text { Ground Motions }\end{array}$} & "Coyote Lake" & 1979 & "Gilroy Array \#4" & CGO & 0.422 \\
\hline & $\begin{array}{l}\text { "Darfield_New } \\
\text { Zealand" }\end{array}$ & 2010 & $\begin{array}{l}\text { "Christchurch Botanical } \\
\text { Gardens" }\end{array}$ & DCO & 0.190 \\
\hline & $\begin{array}{l}\text { "El Mayor-Cucapah_ } \\
\text { Mexico" }\end{array}$ & 2010 & $\begin{array}{l}\text { "Westside Elementary } \\
\text { School" }\end{array}$ & EWO & 0.281 \\
\hline & "Imperial Valley-06" & 1979 & "Agrarias" & IAO & 0.472 \\
\hline & "Kobe_Japan" & 1995 & "Port Island (0 m)" & KPO & 0.567 \\
\hline & "Landers" & 1992 & "Yermo Fire Station" & LYO & 0.245 \\
\hline & $\begin{array}{l}\text { "Superstition Hills- } \\
02 "\end{array}$ & 1987 & $\begin{array}{l}\text { "Kornbloom Road } \\
\text { (temp)" }\end{array}$ & SKO & 0.432 \\
\hline & "Westmorland" & 1981 & "Parachute Test Site" & WPO & 0.232 \\
\hline & "Parkfield-02_ CA" & 2004 & "Parkfield - Fault Zone 9" & PPO & 0.153 \\
\hline & "Kocaeli_Turkey" & 1999 & "Yarimca" & KYO & 0.322 \\
\hline
\end{tabular}

Each record was composed of vertical and two perpendicular pivots. Standards and design codes, including but not limited to (Eurocode 8, 2005; ASCE/SEI 7-10, 2013; Standard 2800-15, 2015) normalize earthquake records for nonlinear dynamic analysis by scaling PGA of the ground motion to $1.0 \mathrm{~g}$ and applying the modification factor to them that obtained from comparing the convoluted response spectrum of the selected records to the standard design spectrum in the determined range of Time period for the studied structures. In this study, the records according to the principles of BHRC (2015) have been 
scaled and implemented in numerical modeling using ABAQUS FEM software. After record normalization, the stress and strain outputs of the Karbandi subjected to the near and far-field records have been extracted and brought for further consideration, as explained in the Time History Analysis section.

\subsection{The Failure Criterion}

According to principles of structural mechanics, the failure mechanism in skeleton structures, took place when the formation of plastic hinges makes the whole structure or some parts of it unstable. Since masonry structures are continuous nonhomogeneous elements with low integrity, the determination of failure mechanism for them is more complicated than one-dimensional elements. According to the experimental and numerical outcomes of many pieces of researches (Andreaus, 1996; Noor-E-Khuda et al., 2016; Bui et al., 2019), the ultimate failure of the masonry elements took place in a plane or planes of crack formation in which some part of the masonry become unstable. Hence, the failure of the Timche, which leads to the mechanism of some or all sections of it, was occurred during the formation of the first plane of failure. The failure point is the ultimate plastic strain of the masonry elements extracted from experimental results of masonry prisms in compression and flexure, which were used for compressive and tensile behavior of masonry elements, respectively. The corresponding failure drift in Nonlinear static analysis was considered to be the failure drift of the structure, in which it was comprehensively collapsed, and the analogous Damage Content (DC) of it was deemed equal to one. The zero point of the Damage Content (DC), when the plastic behavior of the structure corresponds to the yield point of the bilinear pushover curve of the Timche, is initiated. Correspondingly the failure content of the Timche for the nearfield and the far-field earthquakes is evaluated.

\section{Numerical Analysis}

Due to the complexity of the structure and controversial time costs of micro-modeling, the numerical modeling of the masonry dome resides in terms of macro-modeling strategy. Macro-modeling approach in most cases, because of far beyond complexity and/or time-consuming procedure of other methodologies, is considered more efficacious for characterization of the structural response of largescale structural elements and buildings (Lourenço et al., 1995; Baloevic et al., 2016; Pantò et al., 2016). Due to its acceptable accuracy, Concrete Damage Plasticity (CDP) failure criterion was employed for simulating the post-failure behavior of the masonry, the parameters of which adjusted according to Material Properties (Section 4.1). Static General analysis for the gravity loads, Nonlinear Implicit analysis for the nonlinear pushover, and Nonlinear Explicit analysis for the nonlinear time history evaluations using ABAQUS FEM software was employed. To perform the explicit analysis, due to the complexity of the masonry, the double-precision analyzing approach was employed. All components of the model were discretized using 4-node 3D linear tetrahedron elements (C3D4). Denser meshes consisting of 23961 elements were used in numerical modeling. The FEM model has shown in Fig 5. Fixed supported were considered as boundary conditions. 
The masonry material of the dome, according to experimentally assessed masonry units and mortar samples (Section 4.1), was assumed to have an Elasticity modulus of 2690MPa, and Poisson's ratio of 0.15. For further details of calculating masonry parameters, Eurocode 6 (2005), Kaushik et al. (2007), and Kmiecik and Kamiński (2011) may be referred. The models were subjected to $8000 \mathrm{~N} / \mathrm{m}^{2}$ vertical loads, which derived from the structure's self-weight (the dome thickness is $0.15 \mathrm{~m}$ ), and the roof loads consist of precipitation and human loads.

\subsection{Linear Static Analysis}

The behavior of the dome, natural period, reaction of the structure to vertical loads was investigated using linear static analysis. The linear static analysis was carried out by considering the self-weight of the overall structure and rain and snow loads. Analysis results were surveyed in terms of maximum stress variation and the stress flow of the dome. Stress distribution due to gravity loads in the masonry space dome demonstrates that the maximum values of compressive and tensile stresses in both surfaces of the elements were taking place at the eight main load-bearing pillars of the Timche, which has displayed in Figure 6. The stress flow in Timche to a better understanding of the structure mechanism have presented in Figure 7. According to the figure, it can be deduced the force flow transmits from minor arches to the main vaults and from them to the load-bearing pillars. Results also were shown the compressive stresses are dominant in the majority of members and tension stresses in the structure are negligible. Therefore, dominated stress distribution in the members indicates, despite the level of knowledge of the building era, the structure was constructed skillfully.

Frequency analysis to obtain the natural period of the structure carried out. The outcomes of this analysis correspondingly used in nonlinear pushover analysis. The main frequency of the Timche, according to the results, was about $6.22 \mathrm{~Hz}$. Considering the frequency, the period of the structure is $0.161 \mathrm{Sec}$.

\subsection{Nonlinear Pushover Analysis}

A linearized pushover curve could give an approximation of the assuming yield and collapse point of the Karbandi. To this purpose, the displacement-controlled lateral loads were applied to the structure up to point the first plane of failure, considering the plastic strain of the masonry, was came into view. In this regard, the ultimate strain extracted from the CDP criterion that considered the final failure point of the masonry could also be considered the point of failure in the formation of the failure plane. The bilinear curve shows the capacity of the Karbandi under the lateral load and corresponding displacement subjected to that. Since the probability of the failure in both directions was assumable, the pushover curve and related bilinear curve in both directions were extracted. Resultantly the curve with lesser maximum failure load was considered as the ultimate failure curve of the structure. In Figure 8 linearized pushover curve of the Timche in two perpendicular directions has been illustrated. In Figure 9, the formation of the failure plane concerning the attributed plastic strain in nonlinear pushover analysis for the idealized directions has presented. 
According to the presented results, due to lesser load-bearing parameters, direction 1 should be considered as the critical direction. In Table 4, assuming yield and failure points leading to the simplified bilinear curves and corresponding load-bearing strength of the structure has brought.

Table 4: Bilinear curve and corresponding strength of the nonlinear pushover analysis in perpendicular directions

\begin{tabular}{|llll|}
\hline \multicolumn{2}{l}{ Bilinear Curve in Direction 1 } & \multicolumn{2}{l|}{ Bilinear Curve in Direction 2 } \\
\hline Displacement $(\mathrm{mm})$ & Load $(\mathrm{kN})$ & Displacement $(\mathrm{mm})$ & Load $(\mathrm{kN})$ \\
\hline 0 & 0 & 0 & 0 \\
\hline 13 & 668.7 & 13 & 868.4 \\
\hline 73 & 586.0 & 61 & 748.1 \\
\hline
\end{tabular}

\subsection{Time History Analysis}

Concerning the selected records, the mixed average and envelope response spectrum curves have been compared to the standard design spectrum of BHRC (2015) presented in Figure 10. According to the scaling principles of BHRC (2015), the mixed response spectrum of the records between 0.2T and 1.5T, in which $\mathrm{T}$ is the natural period of the structure, could not be less the $90 \%$ of the standard spectrum or modification coefficient is employed. Since the scaling principles for determining the modification coefficient are almost the same, further principles can also be traced from ASCE/SEI 7-10 (2013) and Eurocode 8 (2005). Through the numerical time history analysis, the rest of the required data for extraction of the DC value of studied records were obtained. The plastic strain at final stage of loading for the studied records has been illustrated in Figure 11.

\section{Damage Content}

As explained formerly, the damaged content according to the provided principles in Numerical Analysis (Section 5) computed. Resultantly the DC at each stage of earthquake application with considering the corresponding displacement, the final failure of which is assuming according to the formation of analogous plastic strain failure plane, obtained and for perpendicular directions in both far-filed and nearfield earthquakes respectively presented in Figure 12 and Figure 13. In the studied curves, the failure, when the $\mathrm{DC}$ reaches 1 , was signed.

Due to DCN in far-field earthquakes and due to DCO, EWO, KPO, KYO, and WPO in near-field earthquakes, failure in perpendicular directions of the Timche before the commencement of the strong ground motion has taken place. Failures in the $1^{\text {st }}$ direction in most cases precede the $2^{\text {nd }}$ direction and exist in all cases in which failure happened in both axes. 
In Figure 14, the crown drift of the Karbandi for $X, Y$, and vertical direction subjected to the near-field and far-field ground motions has been depicted.

DCN among the studied far-field records has the critical drift in all of the directions, and its huge weight causes that all displacements to drop below the mean average of the displacements calculated. On the other hand, KYO records in all directions along with DCO in the Y direction and EWO in the vertical direction have had critical drift values. In Figure 15, the strain and kinetic energy differences for the studied records have been shown.

Maximum kinetic energy and minimum strain energy in far-field earthquakes belong to the SBN, while the extremums in near-field strong motions belong to the SKO and PPO records, respectively. Since, duration of the records is different from each other, to get the average, minimum, and maximum values, Fast Fourier Transform (FFT) have employed, according to which time domain converted to the frequency domain. The method makes it possible to compare the damage contents of the records. For convenience and due to symmetry in FFT outcomes, generally, half of the curve is provided. Accordingly, relevant curves for both near-field and far-field records have been illustrated in Figure 16.

Thereafter, the median, mean, minimum, and maximum of the transformed contents have been brought back to the time domain using inverse FFT. Employing IFFT leads to the ultimate mixed damage content value, the $\mathrm{X}$-axis and $\mathrm{Y}$-axis of which is the normalized time and the damaged content, respectively.

Figure 17 provides DC value for Timche under the near-field and far-field ground motions. The values related to the maximum, median, mean, and minimum values of the DC have been extracted. Despite the similarity in occurrence time of the maximum collapse curve of the structure, there are considerable differences in near-field and far-field DC values. In far-field DC, there is a gap between the maximum and median curve which indicates that even though the structure collapsed in some records, it retained functionality in others. Contrary to far-field DC, in near-field, the gap between maximum, median, and mean are very diminutive, and most of the records imposing heavy damages to the structure. Also, minimum values in the near-field IFFT curve are more than fifty percent greater than that of the far-field IFFT curves. Considering all the above, the results emphasize the importance of the near-field records due to the incurred damage. According to the outcomes, the studied structure for a hundred-second lasting far-field earthquake in $50 \%$ of the cases may survive with severe damages however, for the same nearfield earthquake cannot survive for more than 40 seconds. In other words, if a near-field earthquake for the studied Timche has applied most probably before 0.4 of the earthquake occurrence time, the failure and collapse of the structure may take place.

\section{Conclusion}

The study is related to employing an alternative approach to evaluating historical structural systems using FFT, nonlinear static analysis, and nonlinear dynamic analysis. Accordingly, the structural system of Timche Haj-Mohammad-Qoli concerning the architectural concepts, executing aspects (with excavating the historical documents and resources), and current structural stance have been evaluated. 
The concept of damage content (DC) regarding the mechanical characteristics of the used material, including plastic strain, failure plane, and ultimate load-bearing capacity, along with drift value, record selection criteria, and architectural aspects, have been employed. The present structural system is undertaking the vertically applied gravity loads and transferring the force flow with convenience. However, the performed pushover analysis demonstrates the vulnerability of the structure for lateral loads due to the limited drift content of the structural system. At last, since the damage content of the structure due to various records may alter and due to differences in earthquake durations which hindering the possibility of combining the structural response in the time domain a unified structural response in the frequency domain by merging the inversed damage content curves have obtained. The residual outcome reversed to the time domain to make them structurally discussable. The most landmarks results of the study, according to the aforementioned abbreviation, are as follows:

- From architectural aspects, the idea of Karbandi at least could be traced back to the early 15th century, when the eminent mathematician Ghiyath Al-Din Jamshid Masud Al-Kashani, to establish the fundaments of arches with longer spans, redefined and categorized the ancient science of the vaults and arches construction. The newly acquired science was used to build the observatory of Ulug Beg, which would become one of the extraordinary astronomical science discovery places of that era. The byproduct of this breakthrough leads to the employment of geometrical patterns for utilization in places that requires long spans for the required spaces like mosques and covered bazaars (more specifically in cold habitats). The esthetical reflection of this achievement leads to its widespread use for ornamental purposes.

- The historical structure of the Timche was designed in a way to get all of the possible privileges of the compressive strength of masonry units in a manner the least tensile strength due to gravity loads is imposing to the structure. The system has a proper reaction to the lateral loads in the incipient intervals of lateral deformation. However, imposing further lateral deformation exposes the masonry to failure.

- An alternate method of evaluating structural systems, especially for the sensitive structures which must be less affected in their façade and other feature aspects due to their historical importance, aesthetical attraction, etc., with applying Fourier Transform to the damage ratio of time history outcome in the frequency domain has been introduced. The behavior of the vulnerable structures due to earthquake excitations by employing the introduced method along with IDA analysis may most properly determine the failure points of the structural system and the required augmentation, including retrofitting, rehabilitation, and strengthening, with the least interception to the mechanical characteristics of the system, could be employed.

- As expected, the obtained DC from the far-field earthquakes has a lesser ratio comparing to the nearfield earthquakes. It is assumable due to their velocity contents, which most probably affect the structures with short periods, near-field strong ground motions for the low-rise structures have more significant repercussions. According to the outcomes, 3 out of 10 far-field records cause failure in the structure, including one that took place in the perpendicular direction. While 7 out of 10 near-field 
earthquakes lead to the corresponding collapse in the Timche, five of which occurred in perpendicular directions. Concerning the outcomes, generally, a near-field earthquake may finally lead to the collapse of the structure during the initial moments (not more than $40 \%$ of the earthquake duration), while after the eventuation of far-field earthquake, there is a $20 \%$ hope that the structure survives with remnant close to collapse severe damages.

- Since the inverse median curve statistically is representative of more than $50 \%$ of the studied records, while the mean curve is mathematically the average value of the $D C$ for that of the records, the reliability of the median curve due to earthquake aspects may be further than mean curve. Meanwhile, the DC value of the median curve in the far-field and near-field earthquakes on average is about $15.7 \%$ and $14.9 \%$ more than its peer amounts in mean curves, respectively.

\section{Data Availability}

Since some outcomes of this study didn't publish in any other Journal, all data, models, and the results that support the findings of this study are available from the corresponding author upon reasonable request.

\section{Declarations}

\section{CONFLICT OF INTEREST}

The authors whose names are listed immediately below certify that they have No affiliations with or involvement in any organization or entity with any financial interest (such as honoraria; educational grants; participation in speakers' bureaus; membership, employment, consultancies, stock ownership, or other equity interest; and expert testimony or patent-licensing arrangements), or non-financial interest (such as personal or professional relationships, affiliations, knowledge or beliefs) in the subject matter or materials discussed in this manuscript.

\section{References}

1. - 36 CFR 68, the Secretary of the Interior's Standards for the Treatment of Historic Properties (2012), Code of Federal Regulations, 16 U.S.C. 470et seq.

2. - Al-Kashani, G. J. (1427), Meftah Al-Hesab (The Key to Arithmetic), Samarkand, Timurid Empire (In Arabic).

3. - ACl (2004). ACl 228.2R-98: Nondestructive Test Methods for Evaluation of Concrete in Structures, American Concrete Institute $(\mathrm{ACl})$, Farmington Hills, $\mathrm{Ml}$.

4. - ACl (2007). ACl 364.1R-07: Guide for Evaluation of Concrete Structures before Rehabilitation, American Concrete Institute (ACl), Farmington Hills, MI.

5. - ACI (2008). ACI 201.1R-08: Guide for Conducting a Visual Inspection of Concrete in Service, American Concrete Institute (ACl), Farmington Hills, MI. 
6. - ACI (2011). ACI 369R-11: Guide for Seismic Rehabilitation of Existing Concrete Frame Buildings and Commentary, American Concrete Institute (ACl), Farmington Hills, Ml.

7. - ACI (2011), ACI 530: Building Code Requirements and Specification for Masonry Structures, Masonry Standards Joint Committee (MSJC), Reston, VA.

8. - ACI (2013). ACI 562M-13: Code Requirements for Evaluation, Repair, and Rehabilitation of Concrete Buildings and Commentary, American Concrete Institute (ACl), Farmington Hills, Ml.

9. - Aghabeigi, P., Mahmoudi, R., Ahani, E., \& Hosseinian Ahangarnazhad, B. (2020). Seismic Assessment and Retrofitting of the Masonry Building of Mozaffarieh Timche in Tabriz Historic Bazaar. International Journal of Architectural Heritage, 1-26.

10. - Ahani, E., Mousavi, M. N., Rafezy, B., \& Osmanzadeh, F. (2019). Effects of central opening in masonry infill on lateral behavior of intermediate RC frames. Advances in Civil Engineering Materials, 8(1), 23-42.

11. - Ahmadi, M. P. (2014). A basic method for naming Persian Karbandis using a set of numbers. Nexus network journal, 16(2), 313-343.

12. - Andreaus, U. (1996). Failure criteria for masonry panels under in-plane loading. Journal of structural engineering, 122(1), 37-46.

13. - ASCE/Structural Engineering Institute. (2003). Seismic Evaluation of Existing Buildings (ASCE/SEI 31-03), American Society of Civil Engineers.

14. - ASCE/Structural Engineering Institute. (2007). Seismic Rehabilitation of Existing Buildings (ASCE/SEl 41-06), American Society of Civil Engineers.

15. - ASCE/Structural Engineering Institute. (2013). Minimum Design Loads for Buildings and Other Structures (ASCE/SEI 7-10). American Society of Civil Engineers.

16. - Asteris, P. G., Chronopoulos, M. P., Chrysostomou, C. Z., Varum, H., Plevris, V., Kyriakides, N., \& Silva, V. (2014). Seismic vulnerability assessment of historical masonry structural systems. Engineering Structures, 62, 118-134.

17. - Asteris, P. G., Moropoulou, A., Skentou, A. D., Apostolopoulou, M., Mohebkhah, A., Cavaleri, L., Rodrigues, H., \& Varum, H. (2019). Stochastic vulnerability assessment of masonry structures: concepts, modeling and restoration aspects. Applied Sciences, 9(2), 243.

18. - ASTM C39/C39M-21 (2021). Standard Test Method for Compressive Strength of Cylindrical Concrete Specimens, ASTM International, West Conshohocken, PA, www.astm.org, DOI: 10.1520/C0039_C0039M-21.

19. - ASTM C42/C42M-20 (2020). Standard Test Method for Obtaining and Testing Drilled Cores and Sawed Beams of Concrete, ASTM International, West Conshohocken, PA, www.astm.org, DOI: 10.1520/C0042_C0042M-20.

20. - ASTM C496/C496M-17 (2017). Standard Test Method for Splitting Tensile Strength of Cylindrical Concrete Specimens, ASTM International, West Conshohocken, PA, www.astm.org, DOI: 10.1520/C0496_C0496M-17. 
21. - ASTM C597-16 (2016). Standard Test Method for Pulse Velocity Through Concrete, ASTM International, West Conshohocken, PA, www.astm.org, DOI: 10.1520/C0597-16.

22. - ASTM C1314-07 (2007). Standard Test Method for Compressive Strength of Masonry Prisms, ASTM International, West Conshohocken, PA, www.astm.org, DOI: 10.1520/C1314-07.

23. - ASTM E518 / E518M-10, Standard Test Methods for Flexural Bond Strength of Masonry, ASTM International, West Conshohocken, PA, 2010, www.astm.org, DOI: 10.1520/E0518_E0518M-10.

24. - ASTM E519 / E519M-10, Standard Test Method for Diagonal Tension (Shear) in Masonry Assemblages, ASTM International, West Conshohocken, PA, 2010, www.astm.org, DOI: 10.1520/E0519_E0519M-10.

25. - Atamturktur, S., \& Laman, J. A. (2012). Finite element model correlation and calibration of historic masonry monuments. The Structural Design of Tall and Special Buildings, 21(2), 96-113.

26. - ATC (1996). Seismic Evaluation and Retrofit of Concrete Building, Report (ATC-40), Applied Technology Council, California, Vol. 1, USA.

27. - Baloevic, G., Radnic, J., Matesan, D., Grgic, N., \& Banovic, I. (2016). Comparison of developed numerical macro and micro masonry models for static and dynamic analysis of masonry-infilled steel frames. Latin American Journal of Solids and Structures, 13(12), 2251-2265.

28. - Baker, J. W. (2008). Identification of near-fault velocity pulses and prediction of resulting response spectra. Geotechnical earthquake engineering and soil dynamics IV (pp. 1-10).

29. - Bell, A. G. (1903). The tetrahedral principle in kite structure. Judd \& Detweiler.

30. - Betti, M., \& Galano, L. (2012). Seismic analysis of historic masonry buildings: the vicarious palace in Pescia (Italy). Buildings, 2(2), 63-82.

31. - BHRC (2015). Iranian code of practice for seismic resistance design of buildings, Standard 2800-15, 4th Edition, BHRC Publication No. S- 253, Building \& Housing Research Center, Tehran, Iran.

32. - Binda, L., \& Saisi, A. (2005). Research on historic structures in seismic areas in Italy. Progress in Structural Engineering and Materials, 7(2), 71-85.

33. - Boscato, G., Pizzolato, M., Russo, S., \& Tralli, A. (2014). Seismic behavior of a complex historical church in L'Aquila. International Journal of Architectural Heritage, 8(5), 718-757.

34. - Boughton, B., \& Falconer, R. E. (2001). The strengthening and repair of masonry structures using the MARS system. In Proceedings of the International Conference on Structural Faults and Repair, London.

35. - Bozorgmehri, Z. (1992). Hendese Dar Me'mari (Geometry in Architecture). Tehran: Sazmane Mirase Farhangi-ye Keshvar (Iranian Cultural Heritage Organization).

36. - Brandonisio, G., Lucibello, G., Mele, E., \& De Luca, A. (2013). Damage and performance evaluation of masonry churches in the 2009 L'Aquila earthquake. Engineering Failure Analysis, 34, 693-714.

37. - Bui, T. T., Limam, A., \& Sarhosis, V. (2019). Failure analysis of masonry wall panels subjected to inplane and out-of-plane loading using the discrete element method. European Journal of Environmental and Civil Engineering, 1-17. 
38. - Carocci, C. F. (2012). Small centres damaged by 2009 L'Aquila earthquake: on site analyses of historical masonry aggregates. Bulletin of earthquake engineering, 10(1), 45-71.

39. - Carozzi, F. G., Poggi, C., Bertolesi, E., \& Milani, G. (2018). Ancient masonry arches and vaults strengthened with TRM, SRG and FRP composites: Experimental evaluation. Composite Structures, $187,466-480$.

40. - Casarin, F., \& Modena, C. (2008). Seismic assessment of complex historical buildings: application to Reggio Emilia Cathedral, Italy. International Journal of Architectural Heritage, 2(3), 304-327.

41. - Castellazzi, G., D’Altri, A. M., de Miranda, S., Chiozzi, A., \& Tralli, A. (2018). Numerical insights on the seismic behavior of a non-isolated historical masonry tower. Bulletin of Earthquake Engineering, 16(2), 933-961.

42. - Cavalagli, N., Gusella, V., \& Severini, L. (2017). The safety of masonry arches with uncertain geometry. Computers \& Structures, 188, 17-31.

43. - Chen, X., Wang, H., Chan, A. H., \& Agrawal, A. K. (2019). Dynamic failure of dry-joint masonry arch structures modelled with the combined finite-discrete element method. Computational Particle Mechanics, 1-12.

44. - Chiarugi, A., Fanelli, M., \& Giuseppetti, G. (1993). Diagnosis and strengthening of the Brunelleschi Dome. IABSE REPORTS, 441-441.

45. - Chioccarelli, E., \& lervolino, I. (2010). Near-source seismic demand and pulse-like records: A discussion for L'Aquila earthquake. Earthquake Engineering \& Structural Dynamics, 39(9), 1039-1062.

46. - Code, P. (2005). Eurocode 2: Design of concrete structures-part 1-1: General rules and rules for buildings. British Standard Institution, London.

47. - Code, P. (2005). Eurocode 6: Design of masonry structures-Part 1-1: General rules for reinforced and unreinforced masonry structures. Brussels: European Committee for Standardization.

48. - Code, P. (2005). Eurocode 8: Design of structures for earthquake resistance-part 1: general rules, seismic actions and rules for buildings. Brussels: European Committee for Standardization.

49. - Croci, G. (1995). The Colosseum: safety evaluation and preliminary criteria of intervention. Structural Analysis of Historical Constructions, Barcelona.

50. - Cusano, C., Cennamo, C., \& Angelillo, M. (2019). Seismic vulnerability of domes: a case study. Journal of Mechanics of Materials and Structures, 13(5), 679-689.

51. - D'Ayala, D., \& Speranza, E. (2003). Definition of collapse mechanisms and seismic vulnerability of historic masonry buildings. Earthquake Spectra, 19(3), 479-509.

52. - Dogangun, A., \& Sezen, H. (2012). Seismic vulnerability and preservation of historical masonry monumental structures. Earthquake and Structures, 3(1), 83-95.

53. - Doglioni, C., Mongelli, F., \& Pieri, P. (1994). The Puglia uplift (SE Italy): an anomaly in the foreland of the Apenninic subduction due to buckling of a thick continental lithosphere. Tectonics, 13(5), 13091321. 
54. - FEMA (1992). NEHRP Handbook of Techniques for the Seismic Rehabilitation of Existing Buildings, FEMA 172, Federal Emergency Management Agency, Washington, D.C., USA.

55. - FEMA (1997). NEHRP Commentary on the Guidelines for the Seismic Rehabilitation of Buildings FEMA 274, Federal Emergency Management Agency, Washington, D.C., USA.

56. - FEMA (1998). Evaluation of earthquake damaged concrete and masonry wall buildings, FEMA 306, Federal Emergency Management Agency, Washington, D.C., USA.

57. - FEMA (1999). Repair of earthquake damaged concrete and masonry wall buildings, FEMA 308, Federal Emergency Management Agency, Washington, D.C., USA.

58. - FEMA (2009). Unreinforced Masonry Buildings and Earthquakes Developing Successful Risk Reduction Programs, FEMA P-774, Federal Emergency Management Agency, Washington, D.C., USA.

59. - Formisano, A., \& Marzo, A. (2017). Simplified and refined methods for seismic vulnerability assessment and retrofitting of an Italian cultural heritage masonry building. Computers \& Structures, $180,13-26$.

60. - Galassi, S., Misseri, G., Rovero, L., \& Tempesta, G. (2018). Failure modes prediction of masonry voussoir arches on moving supports. Engineering Structures, 173, 706-717.

61. - Garofalo, V. (2016). The Geometry of a Domed Architecture: A Stately Example of Kārbandi at Baghe Dolat Abad in Yazd. Nexus Network Journal, 18(1), 169-195.

62. - Gattulli, V., Antonacci, E., \& Vestroni, F. (2013). Field observations and failure analysis of the Basilica S. Maria di Collemaggio after the 2009 L'Aquila earthquake. Engineering failure analysis, 34, 715-734.

63. - Giuffrè, A. (1991). Readings on Mechanics of Historic Masonry. In Italian: Letture sulla Meccanica delle Murature Storiche, Kappa.

64. - Giuffrè, A. (1993). Safety and conservation of historical centers: The case study of Ortigia, In Italian: Sicurezza e conservazione dei centri storici: Il caso Ortigia, Editrice Laterza, Bari.

65. - Giuffrè, A. (1996). A mechanical model for statics and dynamics of historical masonry buildings. In Protection of the architectural heritage against earthquakes (pp. 71-152). Springer, Vienna.

66. - Haj Ghasem, K. (2004). The second section of the bazaar buildings, Ganjnameh of Islamic architecture of Iran.

67. - IASS WG 8. (1984). Analysis, Design \& Construction of Space Frames. Bulletin of IASS XXV, 1/2, $85 / 85$.

68. - Indirli, M., S. Kouris, L. A., Formisano, A., Borg, R. P., \& Mazzolani, F. M. (2013). Seismic damage assessment of unreinforced masonry structures after the Abruzzo 2009 earthquake: The case study of the historical centers of L'Aquila and Castelvecchio Subequo. International Journal of Architectural Heritage, 7(5), 536-578.

69. - International Code Council ICC (2003). International Building Code, Reston, VA.

70. - Issue No. 120 (2003). "Iranian Concrete Code (ABA)”, Iranian Management Organization, 6th Edition, Tehran, Iran. 
71. - Kaushik, H. B., Rai, D. C., \& Jain, S. K. (2007). Stress-strain characteristics of clay brick masonry under uniaxial compression. Journal of materials in Civil Engineering, 19(9), 728-739.

72. - Kawaguchi, M. (2016). How well do we appreciate the structural legacies? In Proceedings of IASS Annual Symposia (Vol. 2016, No. 11, pp. 1-10). International Association for Shell and Spatial Structures (IASS).

73. - Kmiecik, P., \& Kamiński, M. (2011). Modelling of reinforced concrete structures and composite structures with concrete strength degradation taken into consideration. Archives of civil and mechanical engineering, 11(3), 623-636.

74. - Kohrangi, M., Vamvatsikos, D., \& Bazzurro, P. (2019). Pulse-like versus non-pulse-like ground motion records: Spectral shape comparisons and record selection strategies. Earthquake Engineering \& Structural Dynamics, 48(1), 46-64.

75. - Lagomarsino, S., \& Podesta, S. (2004). Seismic vulnerability of ancient churches: I. Damage assessment and emergency planning. Earthquake spectra, 20(2), 377-394.

76. - Lagomarsino, S., \& Giovinazzi, S. (2006). Macroseismic and mechanical models for the vulnerability and damage assessment of current buildings. Bulletin of Earthquake Engineering, 4(4), 415-443.

77. - Lagomarsino, S. (2012). Damage assessment of churches after L'Aquila earthquake (2009). Bulletin of Earthquake Engineering, 10(1), 73-92.7.

78. - Lourenço, P. B., Rots, J. G., \& Blaauwendraad, J. (1995). Two approaches for the analysis of masonry structures: micro and macro-modeling. HERON, 40 (4), 1995.

79. - Lourenço, P. B. (2002). Computations on historic masonry structures. Progress in Structural Engineering and Materials, 4(3), 301-319.

80. - Lourenço, P. B., \& Roque, J. A. (2006). Simplified indexes for the seismic vulnerability of ancient masonry buildings. Construction and Building Materials, 20(4), 200-208.

81. - Lu, P. J., \& Steinhardt, P. J. (2007). Decagonal and quasi-crystalline tilings in medieval Islamic architecture. science, 315(5815), 1106-1110.

82. - Majewski, S. (2003). The mechanics of structural concrete in terms of elasto-plasticity. Publishing House of Silesian University of Technology, Gliwice.

83. - Memarian, H., Islam, A., \& Mousavian, F. (2014). 15th Century Contribution to the Study of Vaulted Structure in Iran. Iran University of Science \& Technology, 24(1), 1-8.

84. - Mendes, N., Zanotti, S., \& Lemos, J. V. (2020). Seismic performance of historical buildings based on discrete element method: An adobe church. Journal of Earthquake Engineering, 24(8), 1270-1289.

85. - Motro, R. (2009). An anthology of structural morphology. World scientific.

86. - Noor-E-Khuda, S., Dhanasekar, M., \& Thambiratnam, D. P. (2016). Out-of-plane deformation and failure of masonry walls with various forms of reinforcement. Composite Structures, 140, 262-277.

87. - Nooshin, H. (1998). Space structures and configuration processing. Progress in Structural Engineering and Materials, 1(3), 329-336. 
88. - Öztürk, Ş., Bayraktar, A., Hökelekli, E., \& Ashour, A. (2019). Nonlinear structural performance of a historical brick masonry inverted dome. International Journal of Architectural Heritage.

89. - Panella, D. S., Tornello, M. E., \& Frau, C. D. (2017). A simple and intuitive procedure to identify pulselike ground motions. Soil Dynamics and Earthquake Engineering, 94, 234-243.

90. - Pantò, B., Cannizzaro, F., Caddemi, S., \& Caliò, I. (2016). 3D macro-element modelling approach for seismic assessment of historical masonry churches. Advances in Engineering Software, 97, 40-59.

91. - Papadopoulo, A., \& Jazanī, H. (1989). Miđmārīi Islāmī: Islamic Architecture. Markaz-i nashr-i farhangi-i Raja.

92. - Pasticier, L., Amadio, C., \& Fragiacomo, M. (2008). Non-linear seismic analysis and vulnerability evaluation of a masonry building by means of the SAP2000 V. 10 code. Earthquake engineering \& structural dynamics, 37(3), 467-485.

93. - Pellegrini, D., Girardi, M., Lourenço, P. B., Masciotta, M. G., Mendes, N., Padovani, C., \& Ramos, L. F. (2018). Modal analysis of historical masonry structures: Linear perturbation and software benchmarking. Construction and Building Materials, 189, 1232-1250.

94. - Pirnia, M. K., \& Bozorgmehri, Z. (2006). Hendese Dar Memari (Geometry in Architecture). Tehran: Sazman-e Miras-e Farhangi-ye Keshvar, Iranian Cultural Heritage Organization, Tehran, (In Persian).

95. - Portioli, F., \& Cascini, L. (2017). Large displacement analysis of dry-jointed masonry structures subjected to settlements using rigid block modelling. Engineering Structures, 148, 485-496.

96. - Ramos, L. F., \& Lourenço, P. B. (2004). Modeling and vulnerability of historical city centers in seismic areas: a case study in Lisbon. Engineering structures, 26(9), 1295-1310.

97. - Roca, P. (2001). Studies on the structure of Gothic Cathedrals. Historical Constructions, 71-90.

98. - Roca, P., Cervera, M., \& Gariup, G. (2010). Structural analysis of masonry historical constructions. Classical and advanced approaches. Archives of computational methods in engineering, 17(3), 299325.

99. - Rots, J. G. (2001). Sequentially linear continuum model for concrete fracture. Fracture mechanics of concrete structures, 2, 831-840.

100. - Sarhangi, R. (1999). The Sky Within: Mathematical Aesthetics of Persian Dome Interiors. Nexus Network Journal, 1(1), 87-98.

101. - Sarhosis, V., De Santis, S., \& de Felice, G. (2016). A review of experimental investigations and assessment methods for masonry arch bridges. Structure and Infrastructure Engineering, 12(11), 1439-1464.

102. - Scozzese, F., Ragni, L., Tubaldi, E., \& Gara, F. (2019). Modal properties variation and collapse assessment of masonry arch bridges under scour action. Engineering Structures, 199, 109665.

103. - Secretary of the Interior. (1995) Standards for the Treatment of Historic Properties: With Guidelines for Preserving, Rehabilitating, Restoring \& Reconstructing Historic Buildings, National Park Service, Washington D.C. 
104. - Severini, L., Cavalagli, N., DeJong, M., \& Gusella, V. (2018). Dynamic response of masonry arch with geometrical irregularities subjected to a pulse-type ground motion. Nonlinear Dynamics, 91(1), 609624.

105. - Sevim, B., Bayraktar, A., Altunişik, A. C., Atamtürktür, S., \& Birinci, F. (2011). Assessment of nonlinear seismic performance of a restored historical arch bridge using ambient vibrations. Nonlinear Dynamics, 63(4), 755-770.

106. - Sharbaf, A. (2006). Gereh va Karbandi (Gereh and Karbandi). Tehran: Sazman-e Miras-e Farhangi-ye Keshvar, Iranian Cultural Heritage Organization, Tehran, (In Persian).

107. - Solan, B., Ettema, R., Ryan, D., \& Hamill, G. A. (2020). Scour Concerns for Short-Span Masonry Arch Bridges. Journal of Hydraulic Engineering, 146(2), 06019019.

108. - Solan, B., Nowroozpour, A., Clopper, P., Watters, C., \& Ettema, R. (2019, September). Scour-induced failure of masonry arch bridges: Causes and countermeasures. In E-proceedings of the 38th IAHR World Congress.

109. - Stach, E. (2010). Structural morphology and self-organization. Journal of the International Association for Shell and Spatial Structures, 51(3), 217-231.

110. - Vicente, R., Lagomarsino, S., Ferreira, T. M., Cattari, S., \& da Silva, J. M. (2018). Cultural heritage monuments and historical buildings: Conservation works and structural retrofitting. In Strengthening and retrofitting of existing structures (pp. 25-57). Springer, Singapore.

111. - Wang, T., \& Hsu, T. T. (2001). Nonlinear finite element analysis of concrete structures using new constitutive models. Computers \& structures, 79(32), 2781-2791.

112. - Zampieri, P., Zanini, M. A., \& Faleschini, F. (2016). Influence of damage on the seismic failure analysis of masonry arches. Construction and Building Materials, 119, 343-355.

113. - Zampieri, P., Zanini, M. A., Faleschini, F., Hofer, L., \& Pellegrino, C. (2017). Failure analysis of masonry arch bridges subject to local pier scour. Engineering Failure Analysis, 79, 371-384.

114. - Zampieri, P., Cavalagli, N., Gusella, V., \& Pellegrino, C. (2018). Collapse displacements of masonry arch with geometrical uncertainties on spreading supports. Computers \& Structures, 208, 118-129.

115. - Zampieri, P., Simoncello, N., \& Pellegrino, C. (2019). Seismic capacity of masonry arches with irregular abutments and arch thickness. Construction and Building Materials, 201, 786-806.

\section{Figures}



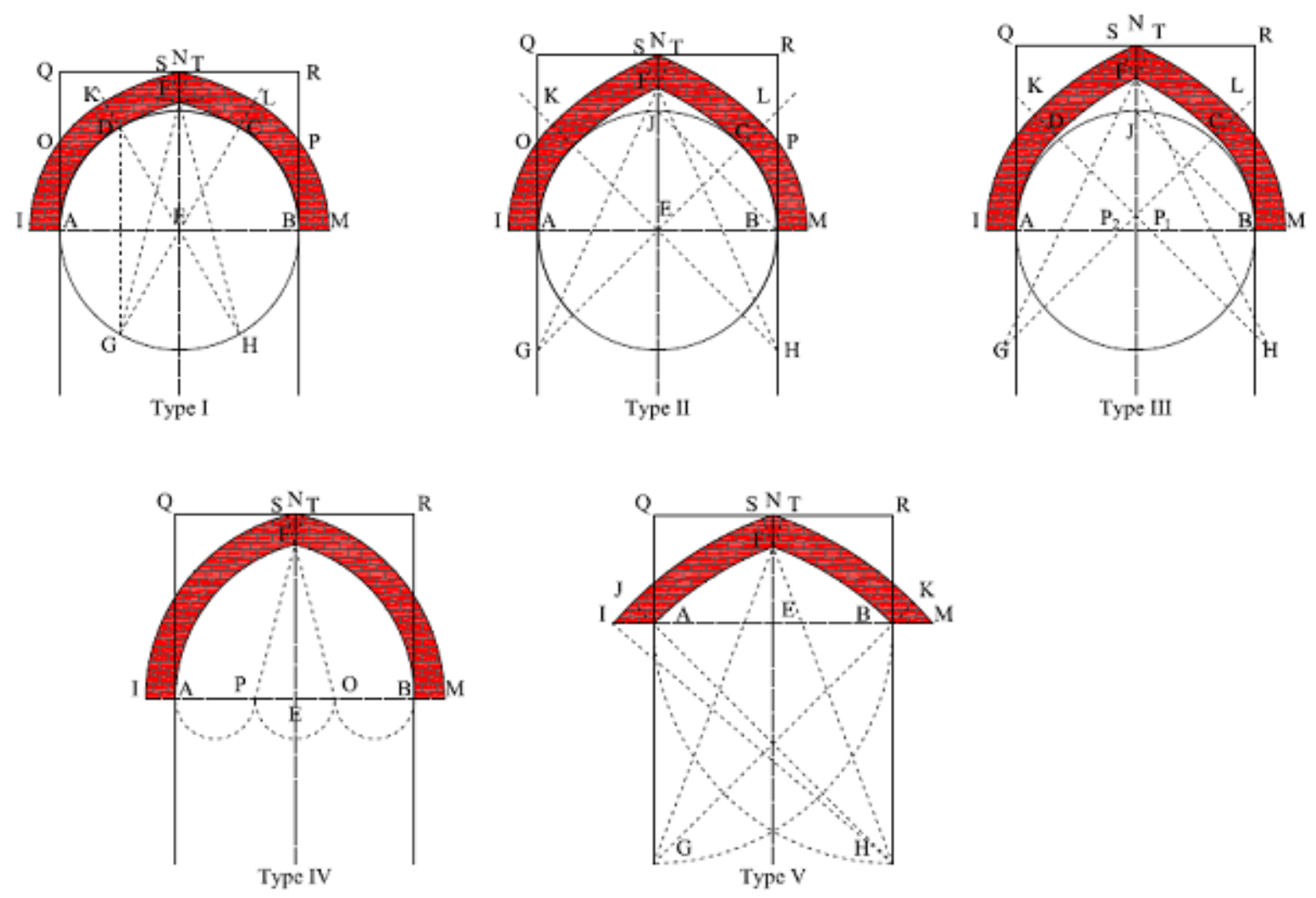

\section{Figure 1}

Redefined and introduced 5 widespread Chefd types according to the mathematical calculations of AlKashani. All of the ancient arch types were reordered and mathematically reconsidered, for the possibility of utilization, in the upcoming future of that era. The obtained results were assembled in the book named Key to Arithmetic. 


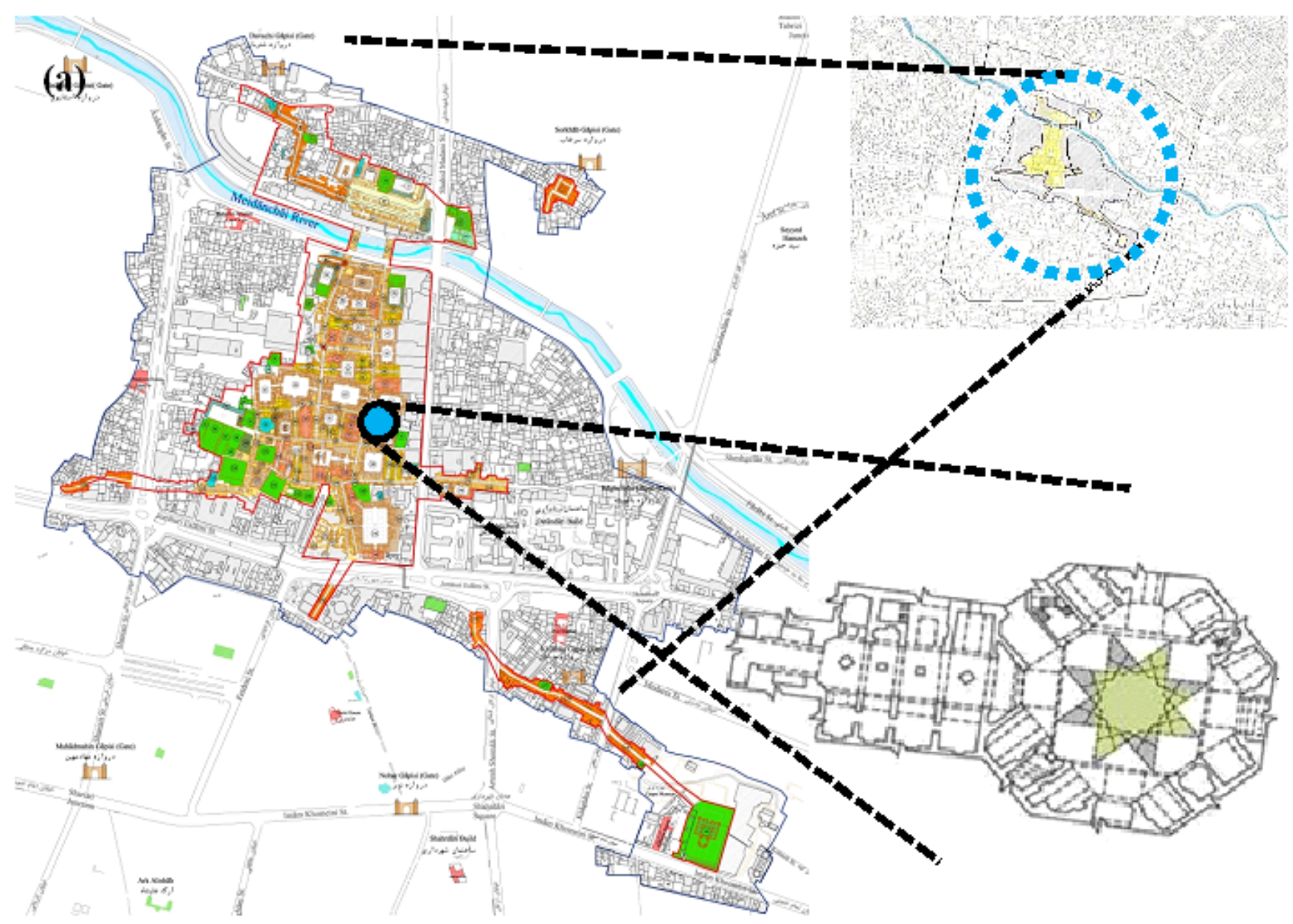

(b)

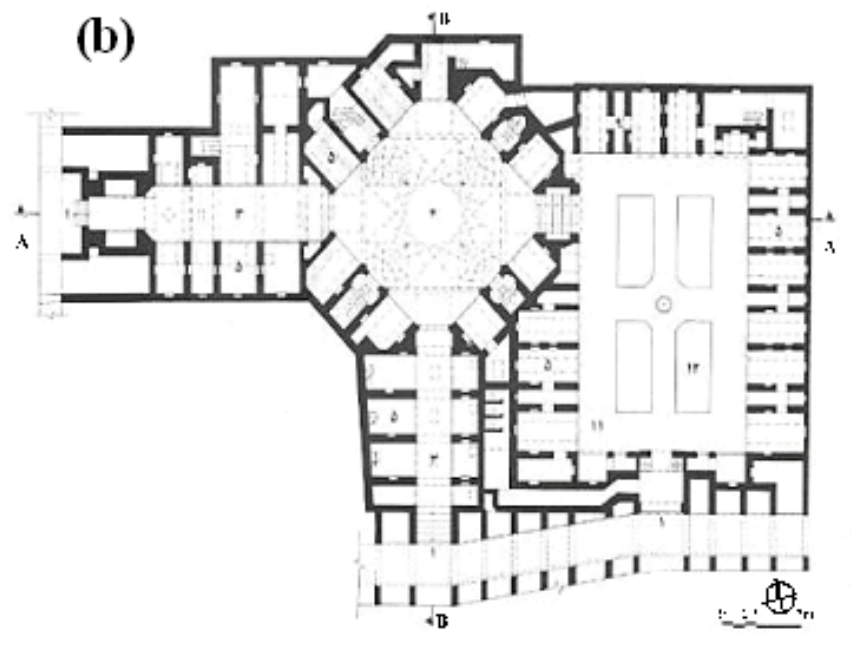

Suclion $A-1$
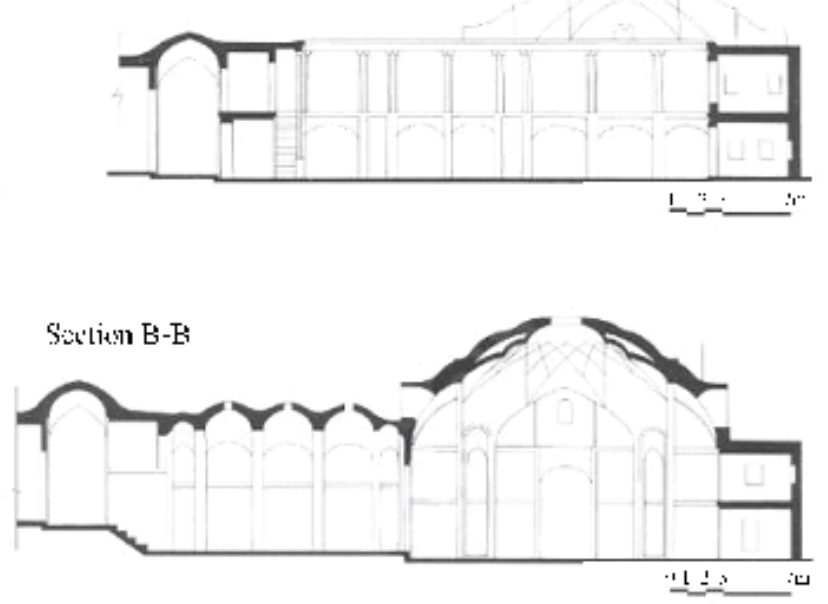

\section{Figure 2}

Timche Haj-Mohammad-Goli of Tabriz Historical Bazaar (a) Geographical location of the site; (b) 2D plan view and cross sectional views 

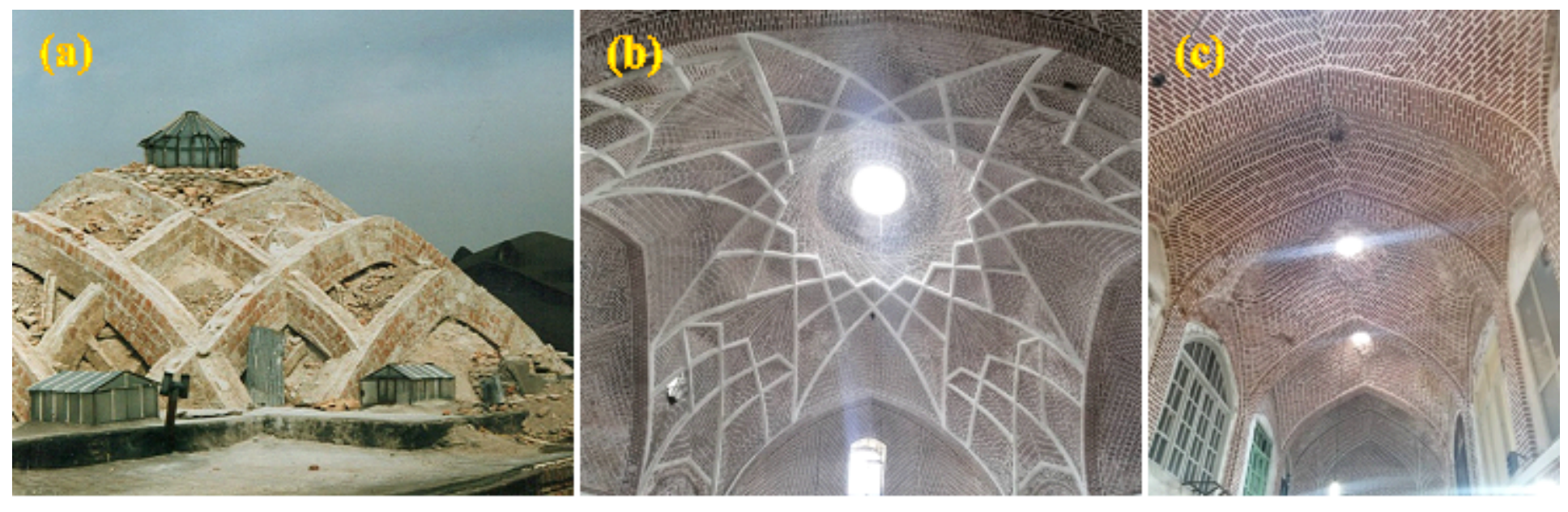

Figure 3

The structural and architectural appearance of the Timche Haj-Mohammad-Qoli's Karbandi; (a) The hidden ribbed arches outside of the building increasing the load-bearing capacity of the Karbandi; (b) A final feature of Karbandi in which two rows of the highest components have been removed; (c) The western Rasteh (entrance) that connects the main passage of Bazaar to the Timche.
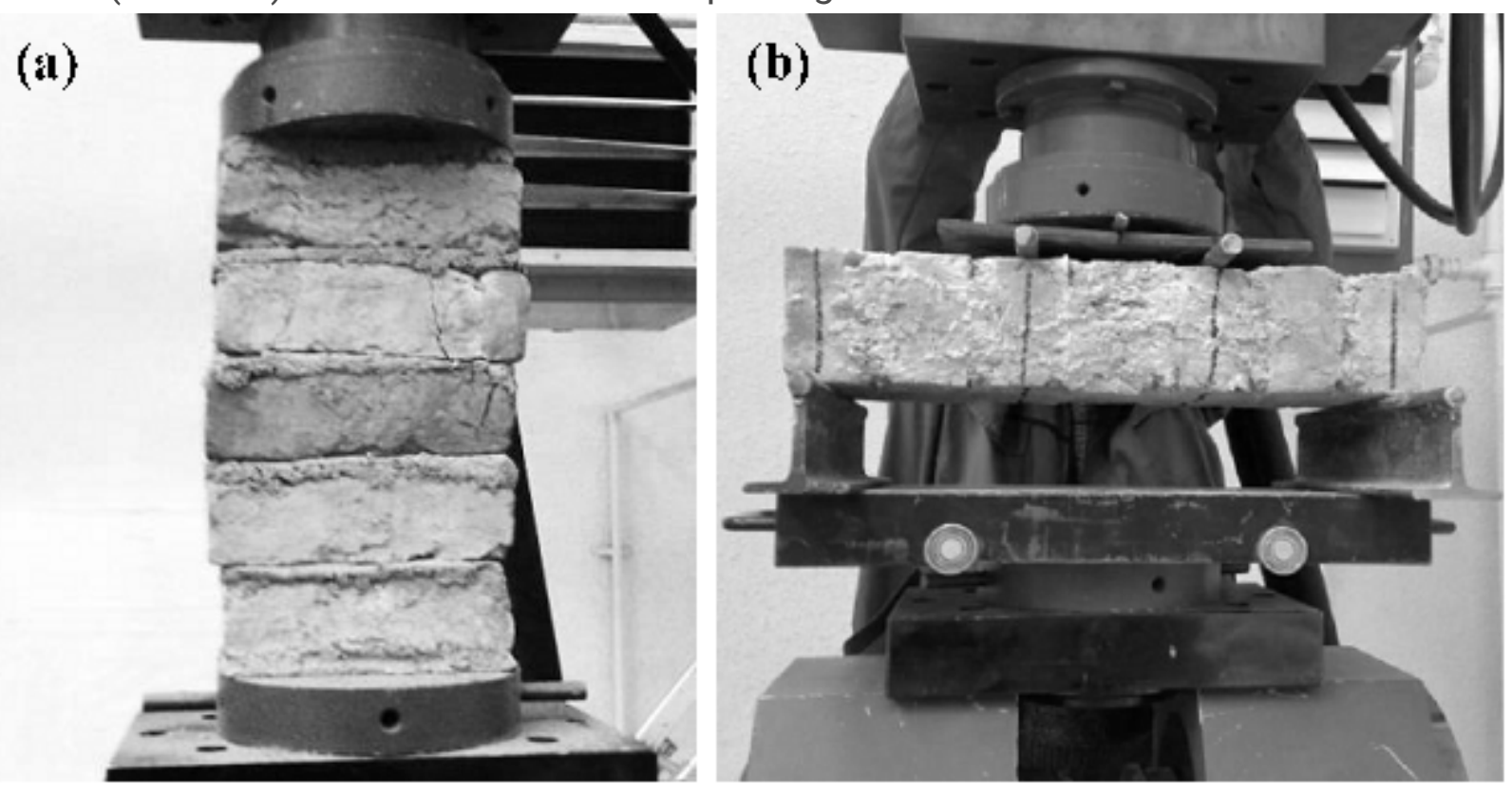

\section{Figure 4}

Material tests of prepared samples; (a) Compression strength test according to ASTM C1314-11 (2011); (b) Flexural bond strength test according to ASTM E518/E518M-10 (2010). 

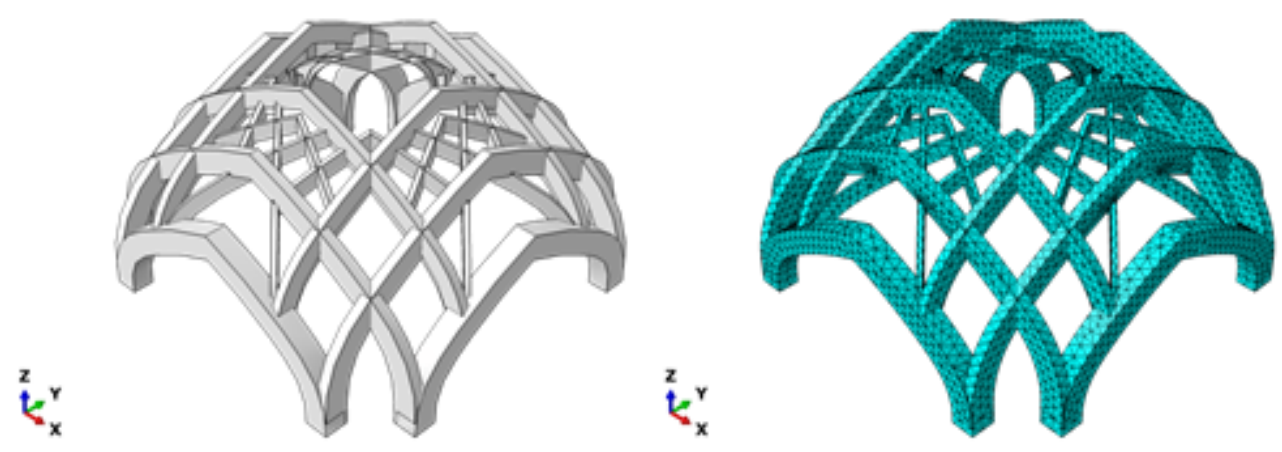

Figure 5

Numerical FEM model of Timche Haj-Mohammad-Qoli, simulated by macro-modeling approach
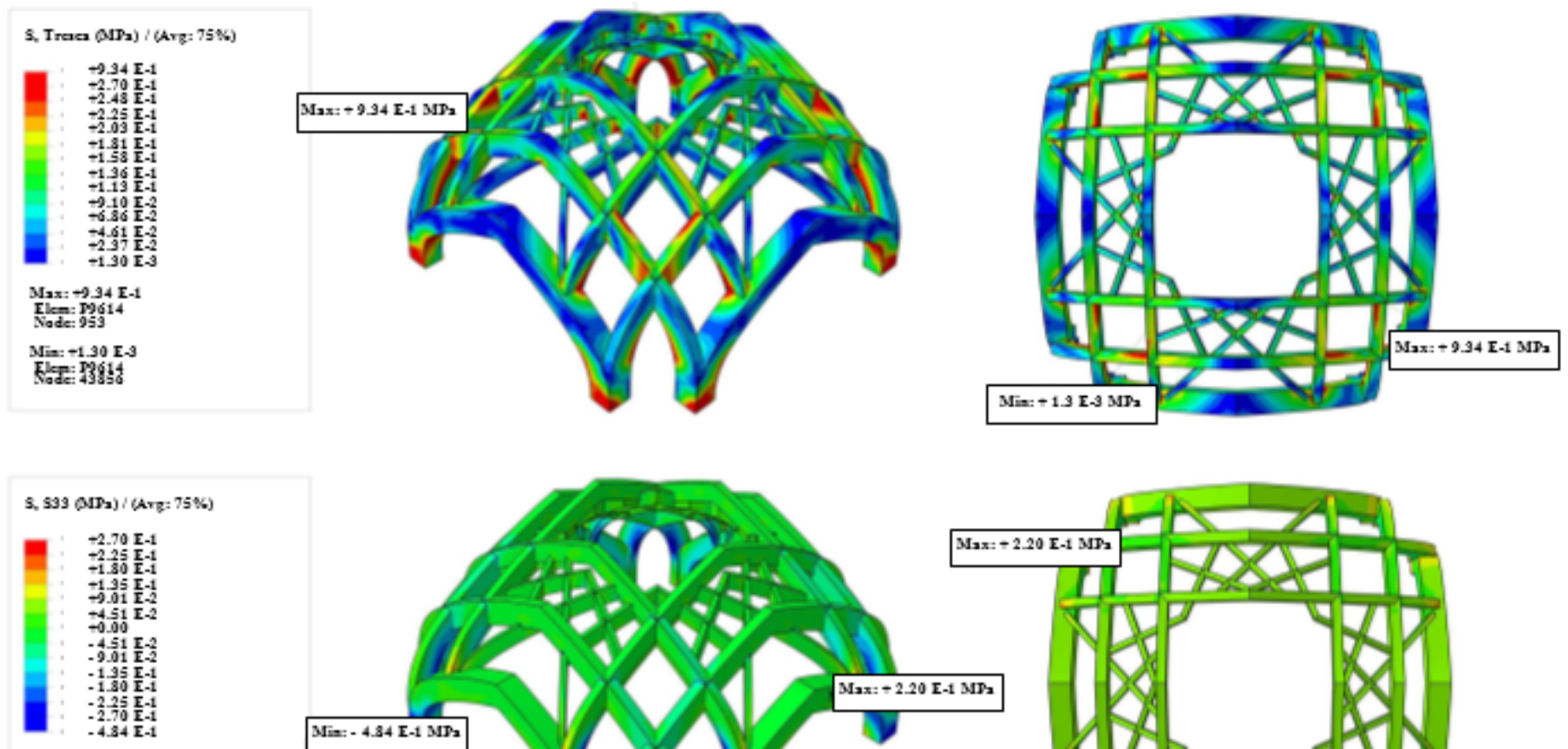

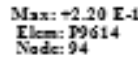

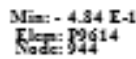
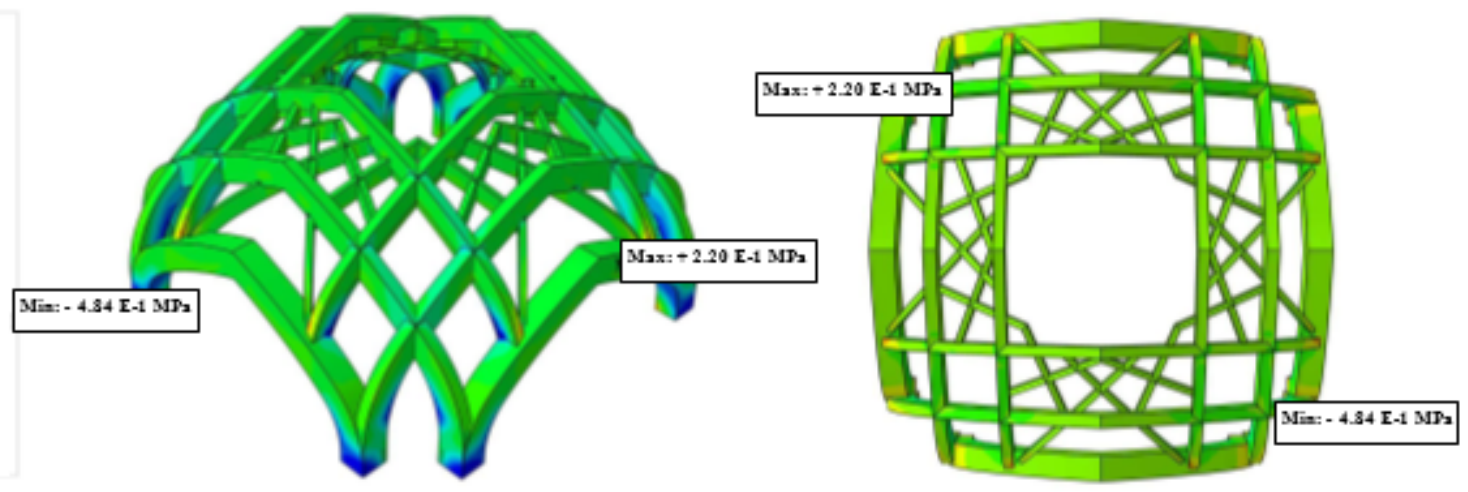

\section{Figure 6}

Distribution of compressive and tensile stresses by employing Tresca criterion and maximum principal stress in gravity direction. 

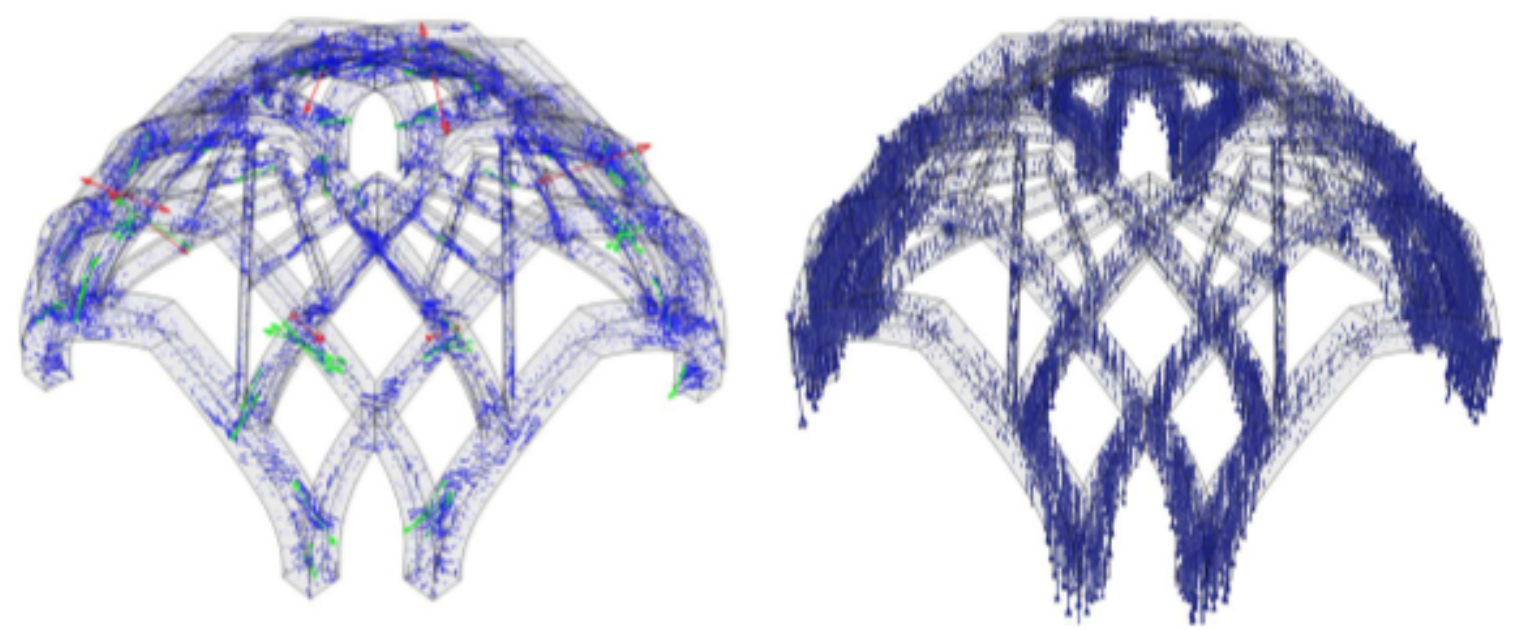

Figure 7

Stress flow within the main load-bearing elements of the Timche by considering 3D and gravity directions. The stress flow concentration in the corners of the Timche to convey the final flow to the endpoints in the gravity direction is considerable.
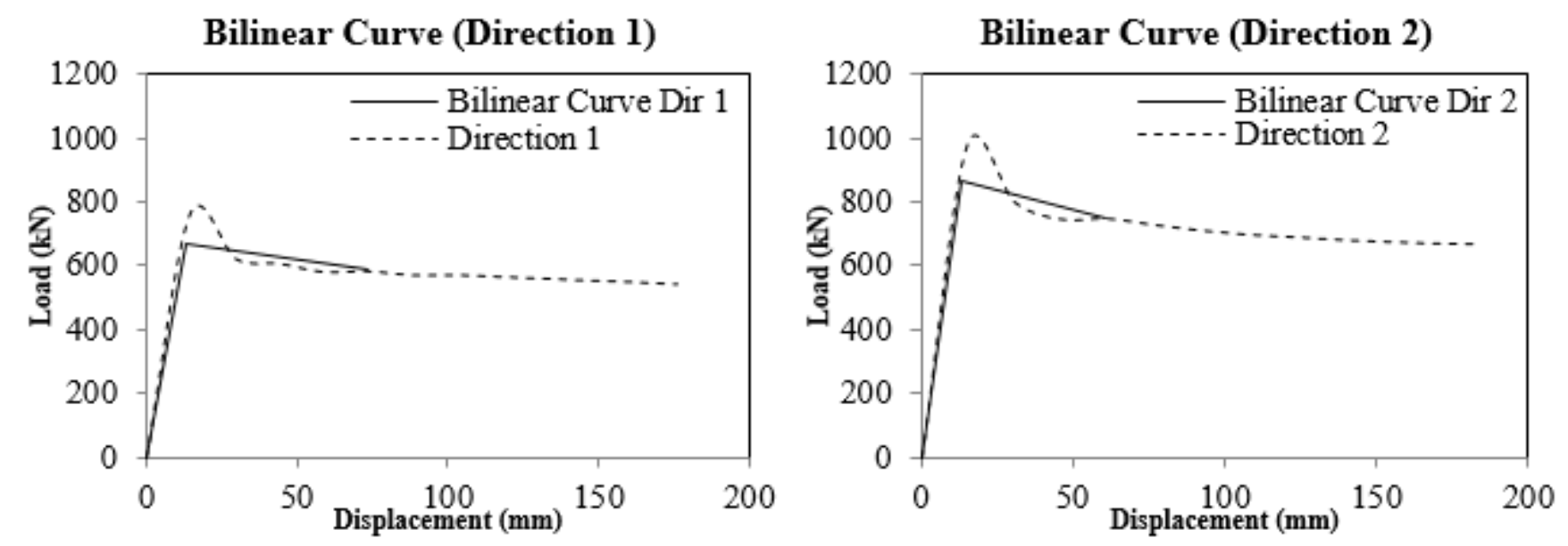

Figure 8

Bilinear Curve of the studied Dome in the perpendicular Directions 

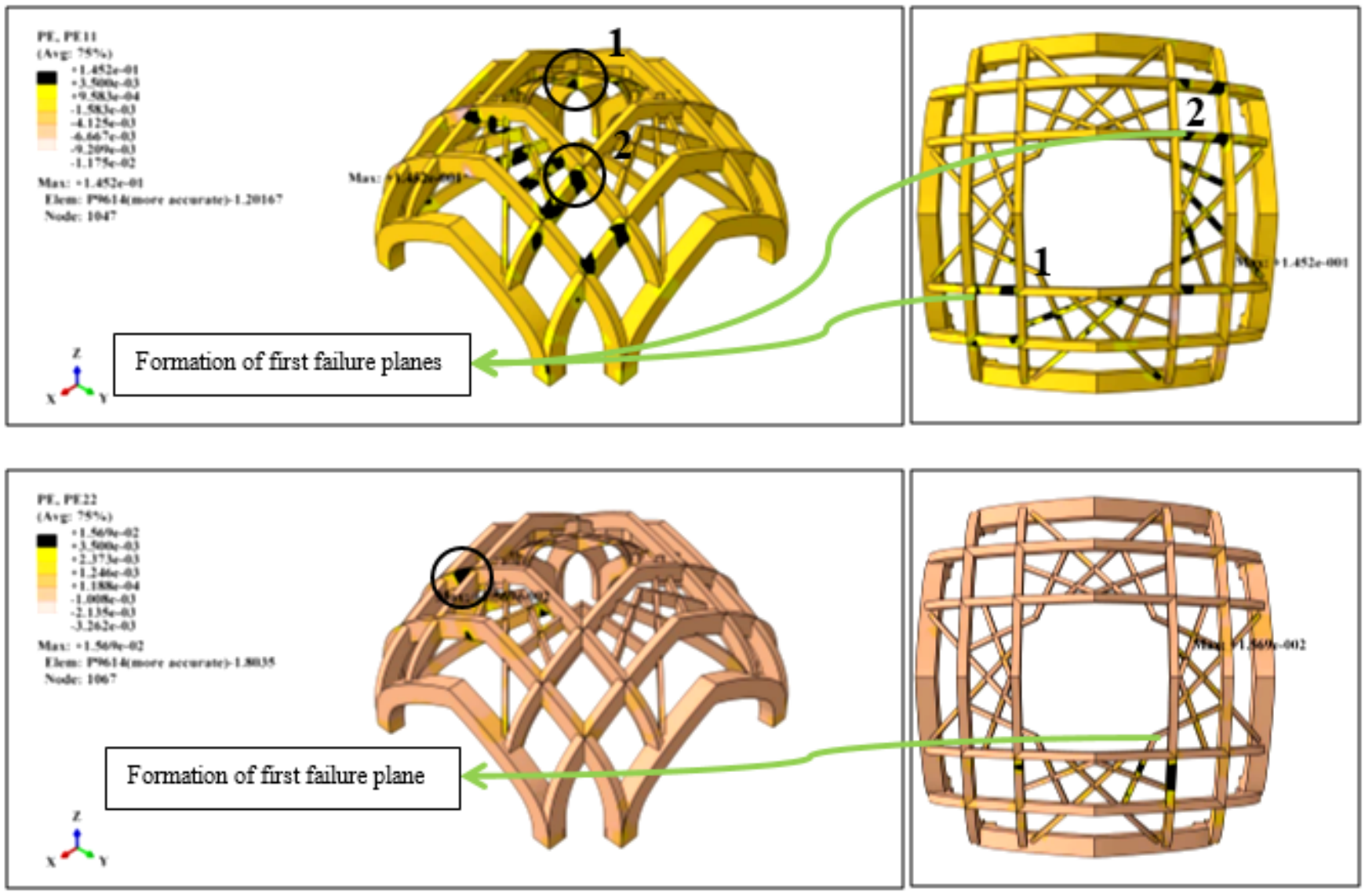

\section{Figure 9}

Formation of failure planes in perpendicular directions due to nonlinear pushover analysis considering the attributed failure parameters
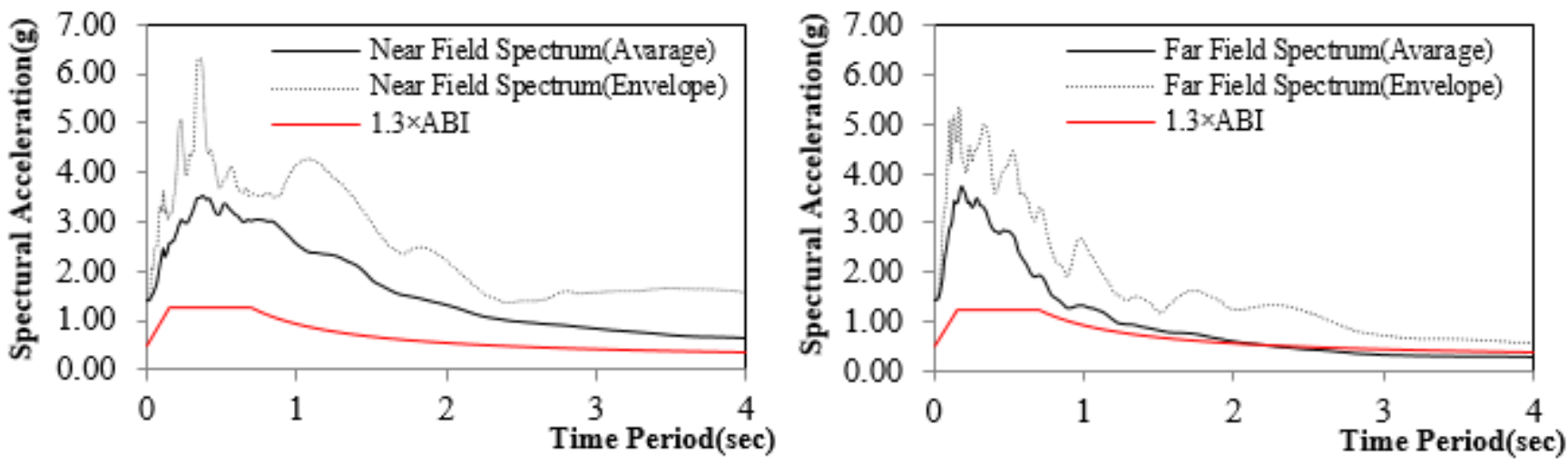

\section{Figure 10}

The mixed average and envelope response spectrum of the near-filed and far-field records compared with the standard design spectrum of BHRC (2015) 


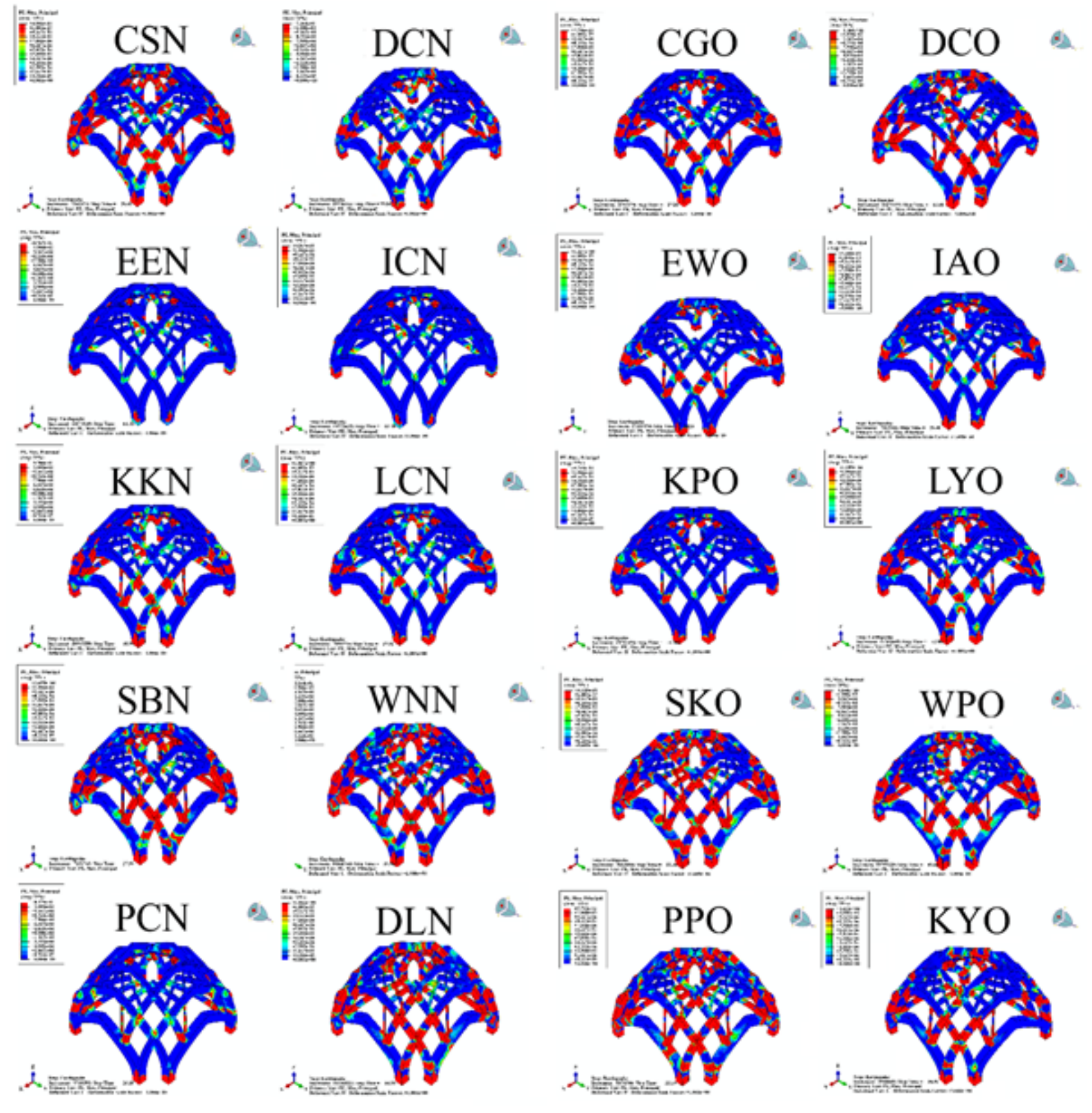

Figure 11

Plastic strain counter of Timche Haj-Moammad-Qoli subjected to strong ground motions 

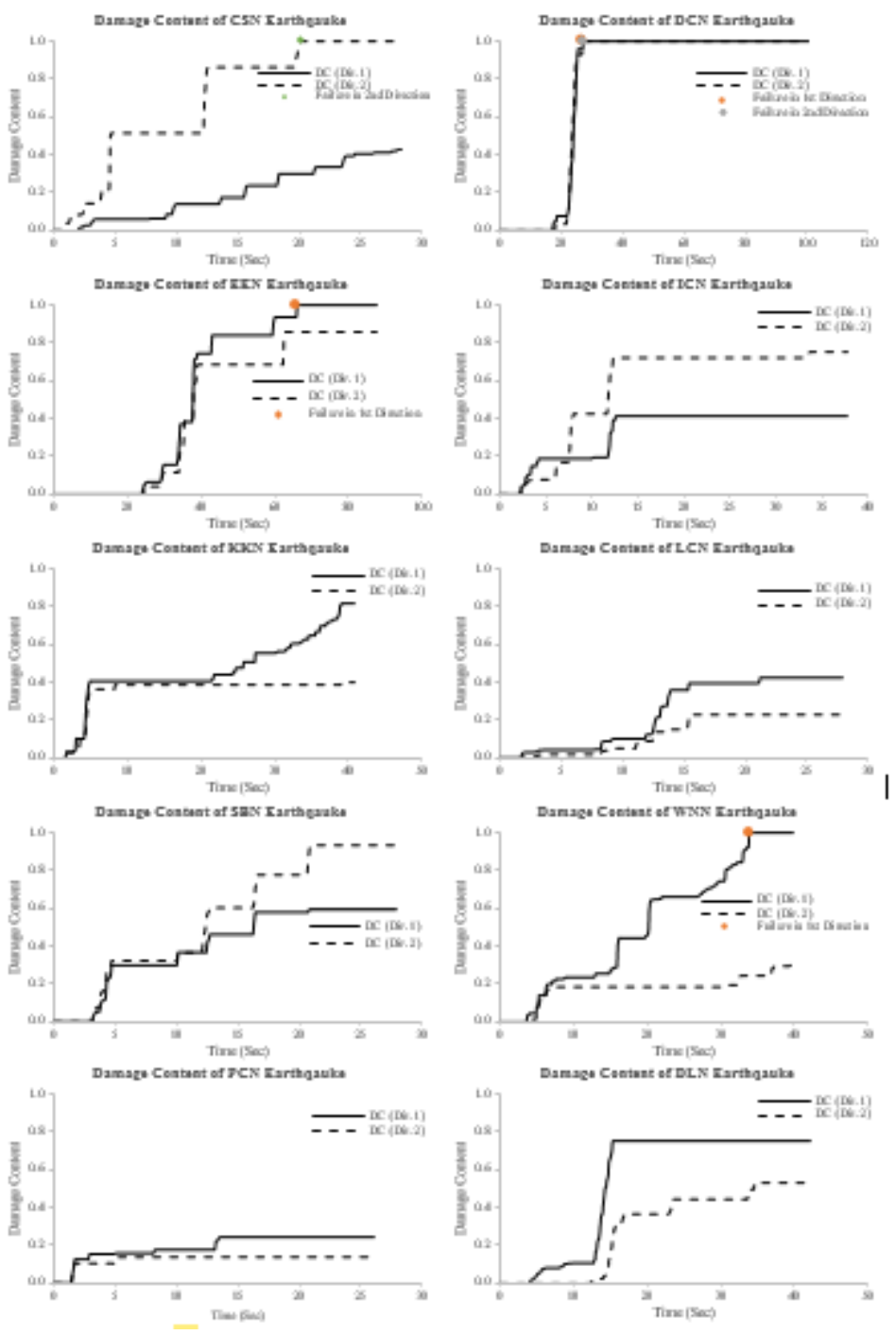

Figure 12

DC value of far-field ground motionsin perpendicular directions 

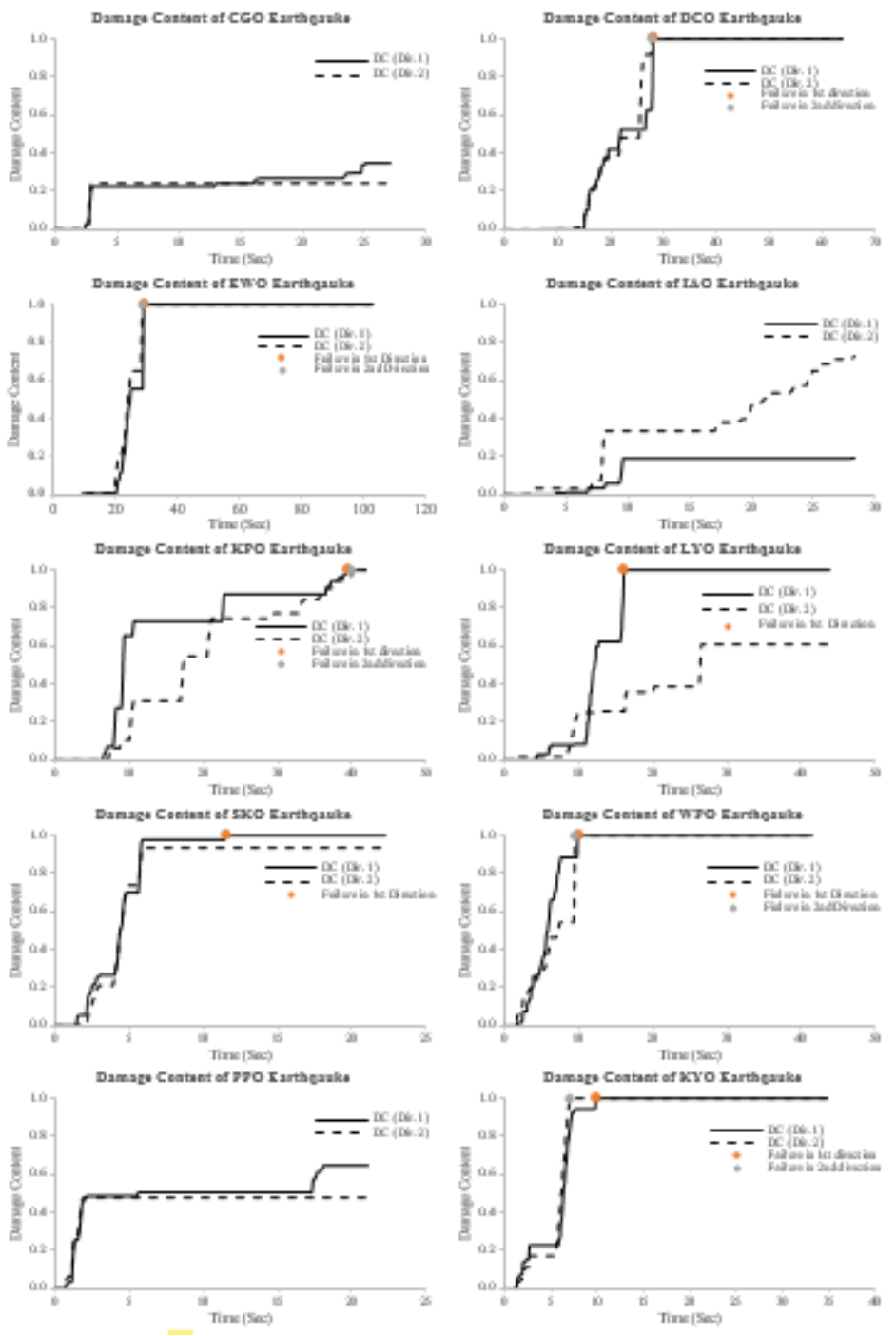

Figure 13

DC value of near-field ground motions in perpendicular directions 
X Direction-Far-field

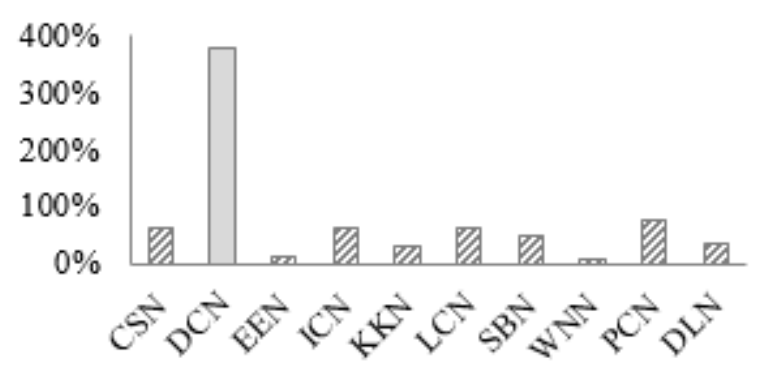

Y Direction-Far-field

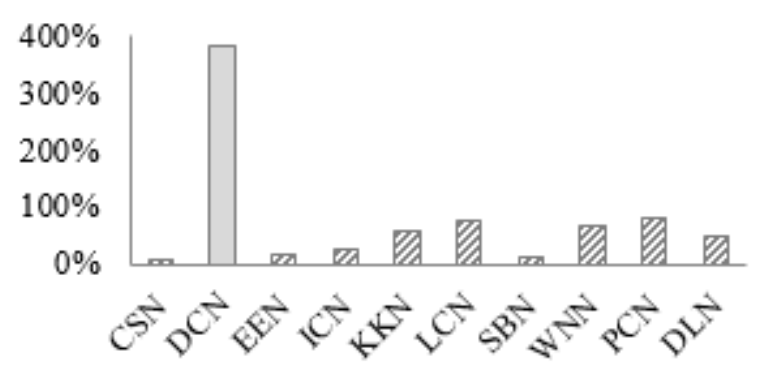

Vertical Driection-Far-field

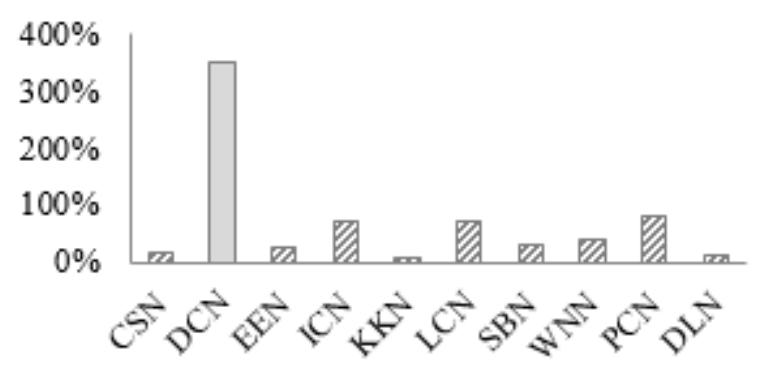

X Direction-Near-field

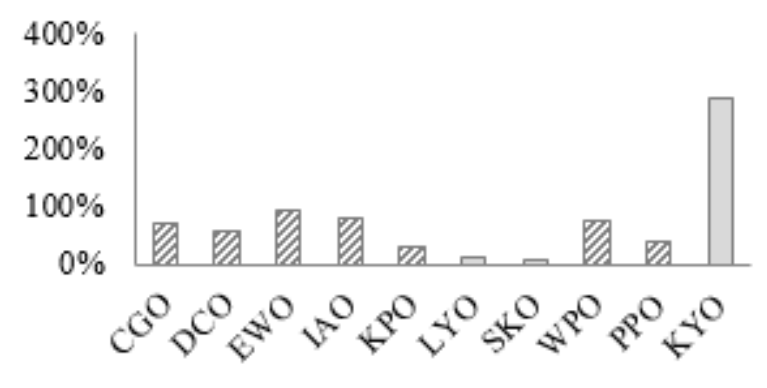

Y Direction-Near-field

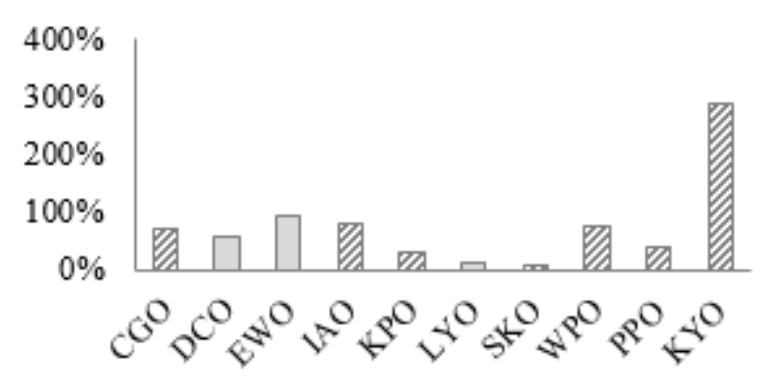

Vertical Driection-Near-field

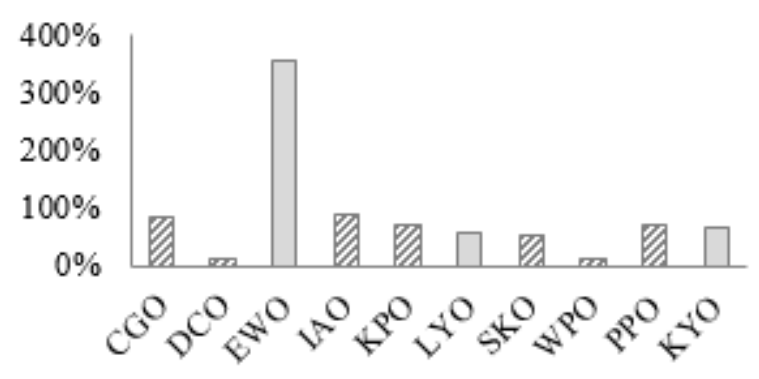

Figure 14

Drift value of the Timche in $X, Y$, and Vertical directions due to the employed earthquake records 
Strain Energy-Far-field

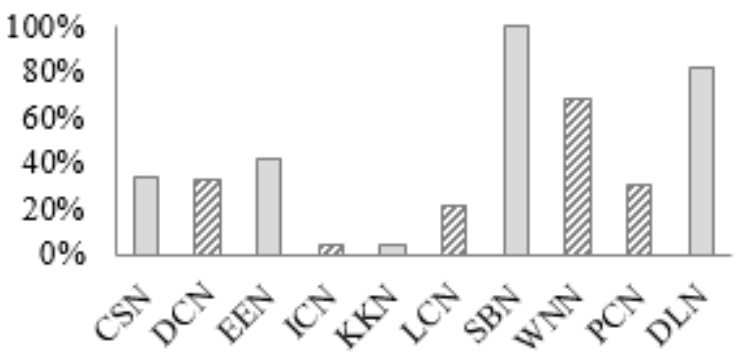

Kinetic Energy-Far-field

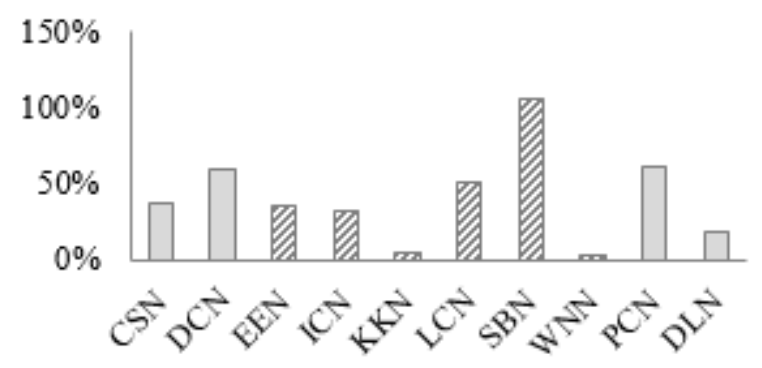

Strain Energy-Near-field

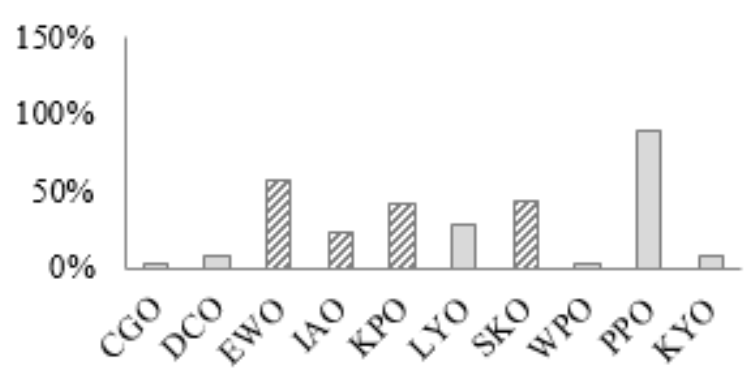

Kinetic Energy-Near-field

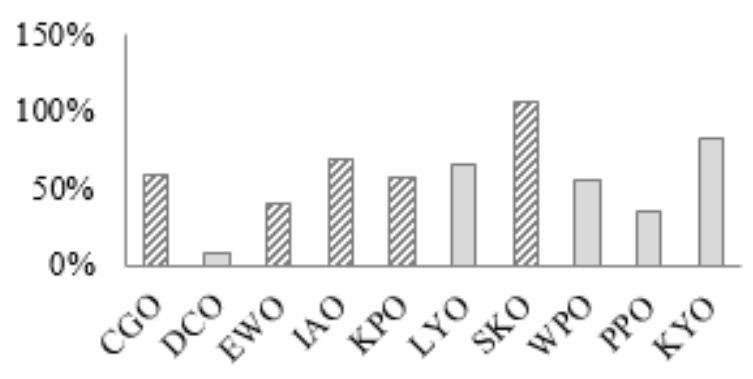

Figure 15

Strain and kinetic energy difference with the mean value for the studied earthquakes (the hatched bars have negative differences) 
Fast Fourier Transform (Far-Field)

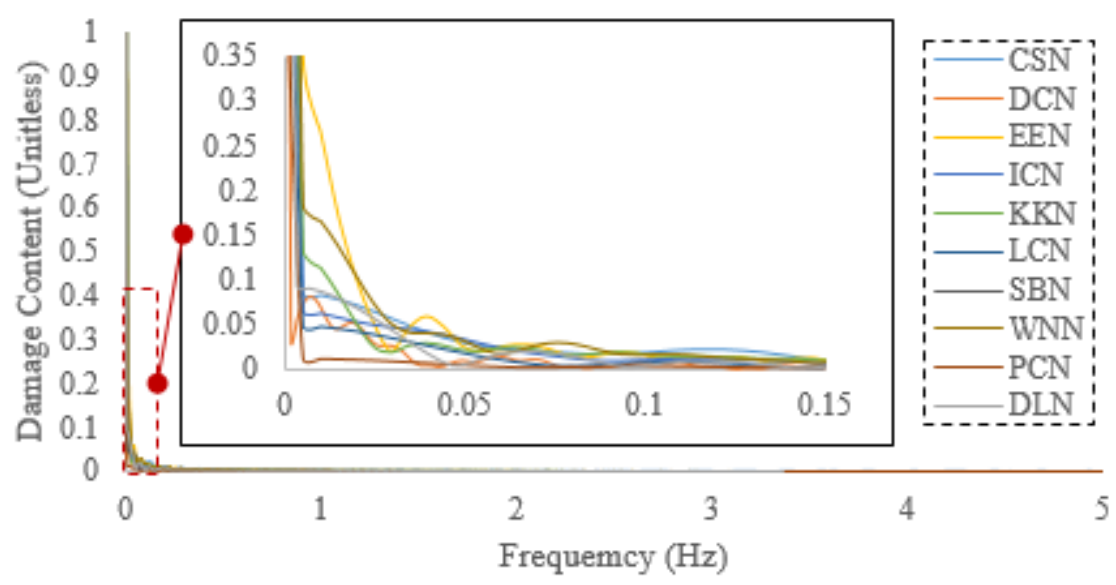

Fast Fourier Transform (Near-Field)

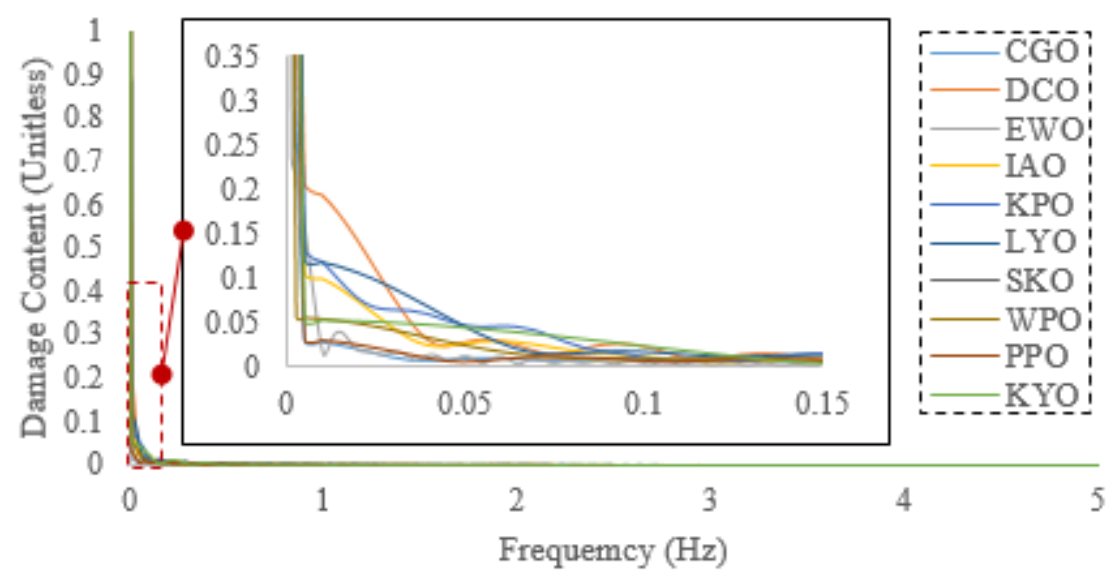

\section{Figure 16}

Fast Fourier Transfer (FFT) of Damage Content (DC) of the near-field and the far-field strong ground motions
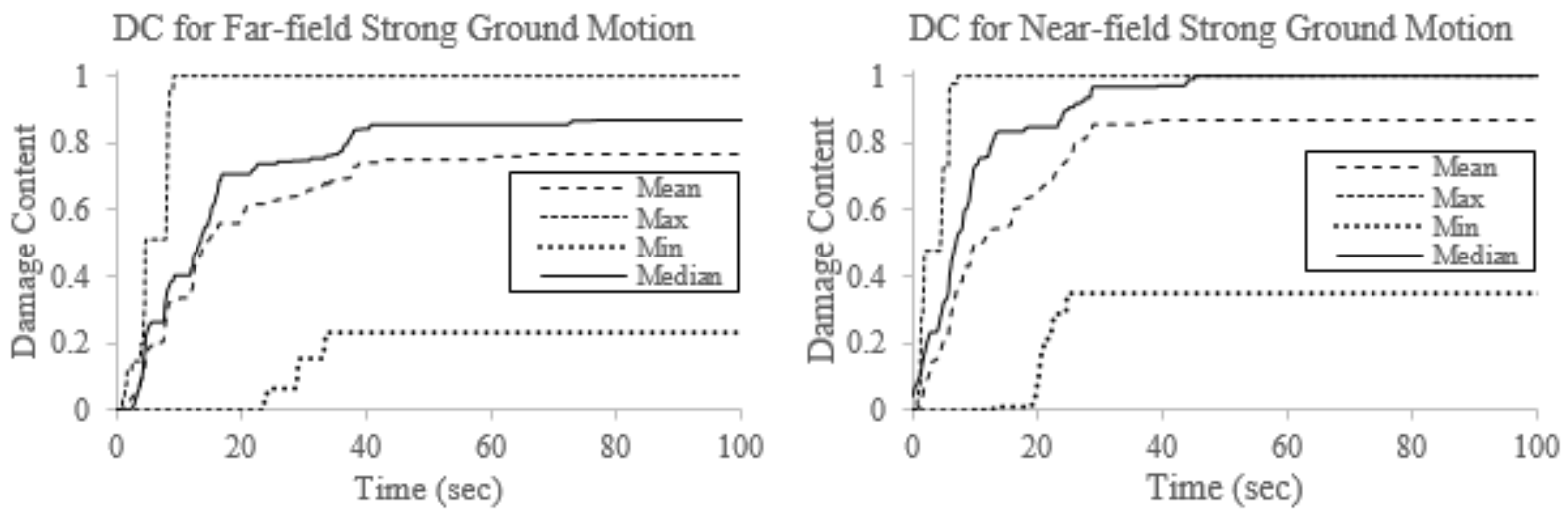

Figure 17 
Inverse Fast Fourier Transfer (IFFT) of Damage Content (DC) of the near-field and the far-field strong ground motions 